\title{
Heat mitigation by greening the cities, a review study
}

\author{
Armaghan Ahmadi Venhari ${ }^{1,2, *}$, Martin Tenpierik ${ }^{2}$, \\ Alireza Mahdizadeh Hakak ${ }^{2}$ \\ ${ }^{1}$ Faculty of Architecture and Urbanism, Shahid Beheshti University, Tehran, District 1, Daneshjou \\ Boulevard, 1983969411, Iran \\ ${ }^{2}$ Faculty of Architecture and the Built Environment, Delft University of Technology, \\ Mekelweg 2, 2628 CD Delft, The Netherlands
}

Received: 4 October 2016

Accepted: 22 November 2016

Published online: 28 February 2017

\begin{abstract}
In the past decades, many studies have proposed urban greening as a method to mitigate the rising temperatures in cities and urban heat islands. The cooling effect of urban green spaces can be divided into two components; cooling intensity and cooling extension. These two components are affected by different factors. This paper provides a review of research on the impact of urban greening on temperature and on the parameters that have an effect on that. Based on this review, two categories that have an effect on cooling intensity and cooling extension were identified: internal factors and external factors. These play an important role in the effectiveness of urban green spaces. As internal factors or indexes, the following were extracted; Size index, Shape index, Vegetation species and Tree canopy coverage are the most common indexes in most of the studies. The external factors can be divided into climate and surrounding properties. A discussion of the reviewed studies reflects the impact of each index on the cooling intensity and cooling extension. The existing methods and techniques for determining these indexes have also been considered in this paper. As such, this study is helpful for designers and planners for decision-making during the design phase.
\end{abstract}

Keywords: urban greening, heat mitigation, cooling extension, cooling intensity

\section{Introduction}

In the world urbanization prospect, the United Nations illustrate that the world urban population will increase by 66 percent by 2050 , from 54 per cent in 2014, which means 2.5 billion people could add to urban populations by 2050(UN 2014) . Rapid urbanization has brought several undesirable changes. The urban heat island (UHI) is one of the most important climatic effects in cities resulting primarily from the capturing and storing of solar radiation by man-made environments and secondarily from the release of waste heat (Voogt and Oke 2003). The UHI effect results in an increased temperature in urban areas compared to their surroundings (Santamouris et al. 2001). Because of the importance of this phenomenon, many researchers all around the world carried out their studies to understand the

\footnotetext{
* Corresponding author: Armaghan Ahmadi Venhari

e-mail: ar-ahmadi@sbu.ac.ir; ahmdadi.armaghan@gmail.com
} 
characteristics of the UHI effect (Arnfield 2003; Ghiaus et al. 2006; Oke 1982). Several techniques are proposed to mitigate this effect in urban areas. Changing materials and adding vegetation are two common strategies in most of these techniques. Using highly reflective materials in buildings and urban spaces (Akbari and Levinson, 2008; Synnefa et al. 2007), the integration of high-tech materials(Karlessi et al. 2011; Zhu and Wu 2001), increasing the amount of vegetation on buildings in the form of green roofs and green facades (Niachou et al. 2001; Santamouris et al. 2012; Zhao and Srebric 2012) and increasing the area of urban greenery in urban parks and green sttreets(Chen and Wong Nyuk 2006; Georgi and Zafiriadis 2006; Shashua-Bar and Hoffman 2000; Taha et al. 1991) are some of the proposed techniques. Rosenfeld believed three strategies are important in mitigating the UHI effect: a. cool roofs, b. cool pavements, and c. vegetation for evapotranspiration (Rosenfeld et al. 1995). Greening the cities as a common technique was proposed in most of the studies. As replacing the natural environment by buildings and reducing the density of green vegetation in urban environments aggravate UHIs (Saito et al. 1991), adding more vegetated areas can be useful to mitigate UHIs.

Heat mitigation resulting from more green spaces in cities have several benefits. One of the important benefits is on human health. Different researchers found that green spaces can reduce heatrelated mortality in cities (Clarke 1972; O'Neill and Ebi 2009). Medina-Ramón, by studying 50 cities in the USA illustrated that extreme heat may increase mortality by up to $5.74 \%$ (Medina-Ramón and Schwartz 2007). In a similar research in 15 European cities, Baccini showed that high summer ambient temperatures affected the rate of mortality, especially in three Mediterranean cities (Barcelona, Rome, and Valencia) and in two continental cities (Paris and Budapest) (Baccini et al. 2011). Mitigating the effects of heat waves by greening cities is imperative for human health especially for vulnerable groups.

The Social benefit of heat mitigation is making cities more livable. Thermal comfort encourages people to gather in urban spaces and increases social interactions (Burden 2008; Rhodes et al. 2011). Jan Gehl divided urban activity into three categories: mandatory, voluntary and social activity (Gehl 2013). Heat stress in urban spaces can decrease voluntary and social activities dramatically. Finally, the Economic effect of greening the cities based on decreasing energy demand is undeniable. A higher temperature in urban spaces causes a higher energy demand for cooling to improve thermal comfort inside buildings (Tremeac et al. 2012). Akbari, Pomerantz, and Taha (Akbari et al. 2001) found that every $1 \mathrm{~K}$ increase in outdoor air temperature can increase the energy consumption of buildings in Los Angeles (L.A.) by $2-4 \%$. They estimated that in these cities $5-10 \%$ of the electricity is required to decrease the temperature inside the building with around 0.5-3.0K. Shen(Shen et al. 2013) showed that a $0.5^{\circ} \mathrm{C}$ temperature increase increases the cooling demand of office buildings in the Hangzhou Metropolitan Area of China with about 10.8\%. One well-known strategy to reduce the air temperature in the city and consequently the energy demand of buildings for cooling is the use of outdoor greening. Simpson and McPherson(Simpson and McPherson 1998) have estimated that every tree leads to a reduction in cooling costs in residential zones of about $1.9 \%-2.5 \%$ in a hot Mediterranean climate of Sacramento, California . Akbari et al. (Akbari 2009)(1992) reported the results of studies in Phoenix and Sacramento showing that by increasing a number of trees by $25 \%$, the air temperature was reduced by 3.3-5.6 K in the summertime. In a recent review(Mullaney et al. 2015), Mullaney concluded that the economic benefit per tree is between $\$ 21$ and $\$ 159$. In addition to the economic benefit, reduction in energy demand by greening the cities also plays an important role in decreasing pollution and emission of $\mathrm{CO}_{2}, \mathrm{NO}_{2}, \mathrm{PM}_{10}$, and VOCs. For this, absorption via leaf stomata and branches is imperative in removing pollution (McPherson 1998; Nowak et al. 2006).

Based on the mentioned benefits of thermal mitigation by urban greening, this paper reviews the literature on the cooling effect of green spaces and extracts the effectiveness indexes. 


\section{Methodology}

The current study is a systematic review on the thermal effect of urban green spaces. There are two main parameters in previous studies that explain the cooling effect of green spaces: the first one focuses on the cooling intensity of urban greenery as the main parameter to quantify the cooling effect and compares air temperature, surface temperature, and perceptional temperature and the second one is the cooling extension of the vegetation. In the next step, based on literature, the effective factors to enhance heat mitigation were divided into internal and external factors. The internal factors depend on the character of the green space and can be divided into four main indexes: Size index: focus on the size of the vegetated area in the cities for more passive cooling purposes. Shape index: investigate the effect of different shapes on the cooling intensity and cooling extension.Green coverage ratio evaluate the effect of the area of ground covered by plant foliage on heat mitigation. Species: illustrate which kinds of vegetation are more effective for thermal comfort.

For each index, in addition to comparing the results, the applied techniques will be presented as well.

The external factors were divided into natural factors included climate and natural elements and artificial factors based on urban geometry, land use, and traffic. The external factors can have an effect on cooling intensity and cooling distance (extension) of urban green spaces.

As each index plays a different role in the cooling intensity and cooling extension, best approaches were suggested with consideration of the problems and the goals of the design.

\section{Urban green space and its thermal effects:}

Several studies have shown that planted areas are effective in influencing the city's microclimate and they have been recommended as a passive adaptation strategy to reduce thermal stress (Bowler et al. 2010; Gill et al. 2007; Givoni 1991). This cooling effect has been described by different terms. Oke (1987) used "oasis effect" because the direct environment around an isolated moisture source is always cooler than its surroundings in an arid region, due to evaporation cooling (Oke 1987). Kai et al.(1997) explained this phenomenon from the differences in the energy balance of the oasis and its surrounding (Kai et al. 1997). In contrast to urban heat island also the term "urban cool island" (UCI) has been used (Hamada and Ohta 2010); in addition, Green space cool islands (GCI) and cool island intensity (CII) (Skoulika et al. 2014) are the other terms in the literature with the same meaning. Park cooling intensity (PCI) (Feyisa et al. 2014) is another term which defines the cooling effect of a specific type of green space. In this paper, GCI will be used.

Increasing vegetation, both in public and in private spaces can reduce the ambient air temperature by shading and evaporation cooling and altering wind speed and direction (Bernatzky 1982; Santamouris 2007). Shading by preventing the penetration of solar radiation is important for the cooling effect (Kotzen 2003; Shashua-Bar and Hoffman 2000). Liebard indicated that the foliage of a tree can filter 60 to $90 \%$ of the solar radiation and that crouching vegetation also decreases the reflected solar radiation near the ground (Liérbard and De Herde 2005). The amount of shading depends on different parameters like canopy cover, plant species, and plant arrangement in the space. In a study in Lisbon with Subtropical-Mediterranean climate, the difference between shaded and sunny points reached 6.9 $\mathrm{K}$ (Oliveira et al. 2011). This difference is more remarkable in hot and dry climates. As mentioned before, evaporation and transpiration is another way in which vegetation can lower the air temperature. In the process of photosynthesis, plants use solar energy and transpire water, thus increasing the humidity and decreasing the temperature around the leaves. Georgy indicated that transpiration could make a place cooler by around 3.1K (Georgi and Dimitriou 2010). In evapotranspiration cooling,, plant species is the most important factor (Kotzen 2003; Pugnaire and Valladares 1999). The climate is 
another factor that affects evaporation and its cooling benefits (De Bruin and Jacobs 1993). Natural ventilation or wind is a third important factor that can reduce the temperature in the city (Boukhabl and Alkam 2012). GCI can thereby be extended over a larger area improving the thermal conditions in this wider area; this extension of the area depends on many parameters like the surrounding morphology, wind direction and topography (Fryd et al. 2011; Oliveira et al. 2011).

GCI can be considered with two main parameters: cooling intensity and its extension (Honjo and Takakura 1991). The thermal effect of urban greenery is demonstrated in Fig 1. Cooling intensity is defined as the difference between the temperature of the green area and its built-up surroundings. The extension or the range of this effect is the size of the area which is affected by the green space.

\section{WIND DIRECTION}

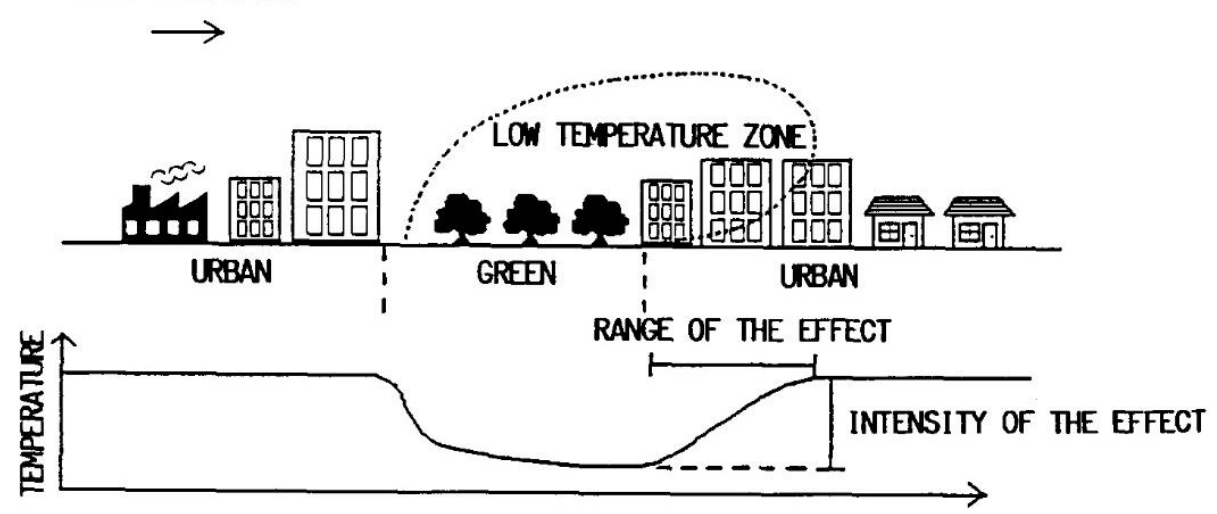

Fig. 1 The cooling effect of an urban green space (Honjo and Takakura 1991).

\subsection{Cooling intensity}

The cooling intensity, as the first important parameter to quantify the cooling effect of greenery, determines the magnitude of the thermal effect of urban green spaces. Cooling intensity has been studied by comparing air temperature, surface temperature and human thermal perception of a green space and its surroundings.

\section{Air temperature}

Parks have a special place among urban green spaces which reduce air temperature. Sonne (Sonne and Vieira 2000) (2000), after a one-year comparison of a forested park to two residential developments, one with extensive plants and the other with few plants, indicated that the air temperature in the park was lower than in the two residential developments and that a number of trees are important for the extent of the temperature reduction. In 2010, Bowler (Bowler et al. 2010) published a metaanalysis on 24 individual studies on parks. He concluded that the average GCI of parks was $0.97 \mathrm{~K}$. In 2014, Skoulika (Skoulika et al. 2014) concluded from 26 published papers that the thermal effect of parks was from $0.3 \mathrm{~K}$ warmer to $6.9 \mathrm{~K}$ cooler than their surroundings. The differences between these results may be because the selected studies that were part of their analysis were from different climatic regions. In Bowler's meta-analysis, most of the studies were from subtropical and Maritime temperate climates, while in Skoulika's study, Lisbon, Portugal, in a Mediterranean climate had the maximum GCI of about $6.9 \mathrm{~K}$.

Orchards are another type of urban green spaces for which their effect on air temperature has been extensively investigated. Although most orchards are isolated and sometimes not public, they are effective in influencing the microclimate of their surroundings. Rosenfeld (Rosenfeld et al. 1995)(1995) reported a research in Los Angeles over the period 1882 to 1984 that because of an increase in the amount of orchards, the average temperature in the city decreased by $2 \mathrm{~K}$ until the 1930 s and thereafter due to an increasing amount of asphalt, which replaced green spaces, the city became warmer by about 3K. Similarly, in another research in Davis, CA, Taha et al.(Taha et al. 1989) (1989) compared an 
isolated orchard with a bare land to the south and north of it. During clear weather, the results showed that the maximum and minimum temperature in the orchard were 26.0 and $7.5^{\circ} \mathrm{C}$ respectively while they were 28.3 and $5^{\circ} \mathrm{Cin}$ the open areas.

Greening streets is another method for heat stress mitigation which has been studied by several researchers(Nichol 1996; Vailshery et al. 2013). In a study by Shahshua et al.(Shashua-Bar and Hoffman 2000) (2000), 11 vegetated sites were analyzed of which most were streets. They concluded that street geometry, tree characteristics, and shading were important for GCI, that this effect was about 0.5-3 K and that the effect was strongest at noon. Tsiros (Tsiros 2010)(2010) examined five streets in the city of Athens (Greece). He measured the air temperature under the vegetation canopy in the streets and at a reference point and found that the cooling effect was from 0.4 to $2.2 \mathrm{~K}$. A large area shaded by trees and minimum traffic were two main characteristics of the coolest streets.

Urban courtyards and their effective cooling of air temperature have not been studied as much as other greening types. Taleghani et al.(Taleghani et al. 2014) (2014) conducted a study in summer in Portland, USA, and in winter in Delft, the Netherlands. They showed that green spaces in summer and winter had smaller diurnal temperature fluctuation and that in summer a green courtyard was maximum $4.7^{\circ} \mathrm{C}$ cooler than a bare one.

Table 1 lists studies into the cooling impact of urban green spaces based on air temperature. As illustrated in this table, GCI of parks varied between $0.8 \mathrm{~K}$ and $8.6 \mathrm{~K}$. This GCI depends on the climate and the natural environment, the size of the parks, species of the plants and trees and canopy cover; all of which will be examined later in this paper. Although there are many studies which show that urban green spaces are islands of cold in the city, there are some empirical studies which show that sometimes they are warmer than their surroundings (Grimmond et al. 1996; Rchid 2012). One of the reasons is that building cast more shadows that trees. Because of this, a park which is covered only by grass may be warmer than areas with buildings. In addition, Potcher (Potchter et al. 2006) found that the heat released by grass because of its decomposition is an important cause for these increased temperatures. $\mathrm{Lu}(\mathrm{Lu}$ et al. 2012) finally explained that photosynthesis during midday was another reason. Besides, many of the artificial parks were paved by concrete and other materials which absorb more energy than vegetation. If a park is designed with large areas of the paved surface, more than 50\% and little treeand shrub-cover, the air temperature inside the park may be increased (Chang et al. 2007).

Tab. 1 Studies on the impact of urban greening on air temperature.

\begin{tabular}{|c|c|c|c|c|c|}
\hline Ref & City & Type & $\begin{array}{l}\text { Size } \\
\text { (ha) }\end{array}$ & $\begin{array}{l}\text { Studied } \\
\text { index }\end{array}$ & Results \\
\hline $\begin{array}{l}\text { (Bacci et } \\
\text { al. 2003) }\end{array}$ & $\begin{array}{l}\text { Florence, } \\
\text { Italy }\end{array}$ & $\begin{array}{l}6 \text { Private } \\
\text { gardens } \\
\text { with trees }\end{array}$ & $\begin{array}{l}0.02- \\
6.9\end{array}$ & SI , BF & $\begin{array}{l}\text { A nocturnal GCI significantly related to } \\
\text { green area size. The } \mathrm{GCI}_{\max } \text { was reported } \\
\text { from } 0.7-3.5^{\circ} \mathrm{C} \text { based on the size of green } \\
\text { areas. }\end{array}$ \\
\hline $\begin{array}{l}\text { (Barradas } \\
1991)\end{array}$ & $\begin{array}{l}\text { Mexico City, } \\
\text { Mexico }\end{array}$ & 5 Parks & $\begin{array}{l}1.9- \\
9.9\end{array}$ & $\begin{array}{l}\text { SI, ShI, } \\
\text { TCC }\end{array}$ & $\begin{array}{l}\text { The maximum } \Delta \text { Ta between parks and their } \\
\text { surrounding recorded in the afternoon and } \\
\text { equaled to } 5.6^{\circ} \mathrm{C} \text {. }\end{array}$ \\
\hline $\begin{array}{l}\text { (Chang et } \\
\text { al. 2007) }\end{array}$ & $\begin{array}{l}\text { Taipei City, } \\
\text { Taiwan }\end{array}$ & 61 Parks & $\begin{array}{l}0.1- \\
25\end{array}$ & SI, TCC & $\begin{array}{l}\text { GCI is positively related to the area of the } \\
\text { park and percent coverage inside the park. }\end{array}$ \\
\hline $\begin{array}{l}\text { (Saito et al. } \\
\text { 1991) }\end{array}$ & $\begin{array}{l}\text { Kumamoto, } \\
\text { Japan }\end{array}$ & Park & $\begin{array}{l}0.24- \\
2.25\end{array}$ & TCC & $\begin{array}{l}3.8^{\circ} \mathrm{C} \text { difference between the air } \\
\text { temperature of tree-shaded area and } \\
\text { unshaded area }\end{array}$ \\
\hline $\begin{array}{l}\text { (Nichol } \\
1996)\end{array}$ & Singapore & Street & & $\mathrm{BG}, \mathrm{TCC}$ & $\begin{array}{l}\text { The cooling effect around } 1.5-2.8^{\circ} \mathrm{C} \\
\text { between tree canopy cover and built area }\end{array}$ \\
\hline $\begin{array}{l}\text { (Gomez et } \\
\text { al. 1998) }\end{array}$ & $\begin{array}{l}\text { Valencia, } \\
\text { Spain }\end{array}$ & 1 Park & 20 & UG & $\begin{array}{l}\text { Air temperature was dropped around } 2.5^{\circ} \mathrm{C} \\
\text { by green area }\end{array}$ \\
\hline
\end{tabular}


Environment, Earth and Ecology Vol. 1 No. 1 (2017), 5-32

DOI: $10.24051 / \mathrm{eee} / 67281$

Armaghan Ahmadi Venhari et al.

\begin{tabular}{|c|c|c|c|c|c|}
\hline Ref & City & Type & $\begin{array}{l}\text { Size } \\
\text { (ha) }\end{array}$ & $\begin{array}{l}\text { Studied } \\
\text { index }\end{array}$ & Results \\
\hline $\begin{array}{l}\text { (Potchter et } \\
\text { al. 2006) }\end{array}$ & $\begin{array}{l}\text { Tel Aviv, } \\
\text { Israel }\end{array}$ & 3parks & $\begin{array}{l}2.5- \\
3.5\end{array}$ & TCC & $\begin{array}{l}\text { Grass and different amounts of trees effect } \\
\text { on air temperature about } 0.7-2.5^{\circ} \mathrm{C}\end{array}$ \\
\hline $\begin{array}{l}\text { (Georgi } \\
\text { and } \\
\text { Dimitriou } \\
2010 \text { ) }\end{array}$ & $\begin{array}{l}\text { Chania, } \\
\text { Greece }\end{array}$ & 1 Park & 6 & SI, UG & $\begin{array}{l}\text { The maximum reduction in air temperature } \\
\text { in the day and at night was almost similar, } \\
2.6 \text { and } 2.8 \text { respectively, and minimum } \\
\text { reduction at night } 0.5^{\circ} \mathrm{C} \text { was more than } \\
\text { daytime and equaled to } 0,7 \text {. }\end{array}$ \\
\hline $\begin{array}{l}\text { (Srivanit } \\
\text { and Hokao } \\
\text { 2013) }\end{array}$ & Saga, Japan & $\begin{array}{l}\text { University } \\
\text { campus }\end{array}$ & & SI & $\begin{array}{l}\text { Maximum GCI equals to } 2.27 \text { by increasing } \\
20 \% \text { in the number of trees }\end{array}$ \\
\hline $\begin{array}{l}\text { (Jansson et } \\
\text { al. 2007) }\end{array}$ & $\begin{array}{l}\text { Stockholm, } \\
\text { Sweden }\end{array}$ & 1 park & 15 & UG & $\begin{array}{l}\text { A reduction in air temperature in sunset } \\
\text { was at maximum } 2{ }^{\circ} \mathrm{C} \text { while } 0.5-0.8{ }^{\circ} \mathrm{C} \\
\text { during the day }\end{array}$ \\
\hline $\begin{array}{l}\text { (Vailshery } \\
\text { et al. 2013) }\end{array}$ & $\begin{array}{l}\text { Bangalore, } \\
\text { India }\end{array}$ & Street & & TCC & $\begin{array}{l}5.6 \text { reduction in air temperature in street } \\
\text { segments with shadowing trees }\end{array}$ \\
\hline $\begin{array}{l}\text { (Skoulika } \\
\text { et al. 2014) }\end{array}$ & $\begin{array}{l}\text { Athens, } \\
\text { Greece }\end{array}$ & Park & 6 & CL & $\begin{array}{l}\text { The average cooling effect of park was } 3.3 \text { - } \\
3.8 \mathrm{~K}\end{array}$ \\
\hline $\begin{array}{l}\text { (Ahmad } \\
\text { 1992) }\end{array}$ & $\begin{array}{l}\text { Kuala } \\
\text { Lumpur, } \\
\text { Malaysia }\end{array}$ & 4 parks & $\begin{array}{l}1.6- \\
153\end{array}$ & SI & $\begin{array}{l}\text { Based on size of the parks, the GCI was } \\
1.5-4.1^{\circ} \mathrm{C}\end{array}$ \\
\hline $\begin{array}{l}\text { (Katayama } \\
\text { et al. 1993) }\end{array}$ & $\begin{array}{l}\text { Fukuoka, } \\
\text { Japan }\end{array}$ & 1 park & 1.25 & SpI & $\begin{array}{l}\text { A significant relationship between trees } \\
\text { species and GCI was reported and the } \\
\text { maximum GCI was } 2.7\end{array}$ \\
\hline $\begin{array}{l}\text { (Jonsson } \\
\text { 2004) }\end{array}$ & $\begin{array}{l}\text { Gaborone, } \\
\text { Botswana }\end{array}$ & $\begin{array}{l}5 \quad \text { green } \\
\text { areas }\end{array}$ & & TCC & $\begin{array}{l}\text { Dens green spaces were up to } 2^{\circ} \mathrm{C} \text { cooler } \\
\text { than countryside; while sparse green spaces } \\
\text { were warmer. }\end{array}$ \\
\hline $\begin{array}{l}\text { (Thorsson } \\
\text { et al. 2007) }\end{array}$ & $\begin{array}{l}\text { Matsudo, } \\
\text { Japan }\end{array}$ & 1park & 2.1 & TCC & $\begin{array}{l}\text { Grass lawn, forest, playground as a } \\
\text { different feature of the green site were } \\
\text { studied and average GCI was } 1.1 \text {. The GCI } \\
\text { of these features, based on canopy cover, } \\
\text { was different. }\end{array}$ \\
\hline $\begin{array}{l}\text { (Lee et al. } \\
\text { 2009) }\end{array}$ & Seoul, Korea & 2 parks & $\begin{array}{l}1.5- \\
4.2\end{array}$ & UG, LU & $\begin{array}{l}\text { Urban morphology and land use were two- } \\
\text { factor intensified heat stress around parks. }\end{array}$ \\
\hline $\begin{array}{l}\text { (Hamada } \\
\& \quad \text { Ohta } \\
2010)\end{array}$ & $\begin{array}{l}\text { Nagoya, } \\
\text { Japan }\end{array}$ & 1 Park & 147 & TCC & $\begin{array}{l}\text { The air temperature difference between } \\
\text { urban and green areas, in summer, was } \\
\text { more than winter, } 1.9 \text { and } 0.3 \text { respectively. } \\
\text { The greenery during the day was more } \\
\text { effective in heat mitigation than at nights. }\end{array}$ \\
\hline $\begin{array}{l}\text { (Lahme } \\
\text { and Bruse } \\
\text { 2003) }\end{array}$ & $\begin{array}{l}\text { Essen, } \\
\text { Germany }\end{array}$ & 1 Park & & TCC & $\begin{array}{l}\text { The leaf area density as an important } \\
\text { factor could change shadow and air } \\
\text { temperature. } 1.0 \mathrm{~K} \text { average cooling effect } \\
\text { on air temperature between the park and } \\
\text { the densely built-up area was recorded. }\end{array}$ \\
\hline $\begin{array}{l}\text { (Sonne and } \\
\text { Vieira } \\
\text { 2000) }\end{array}$ & Florida, & $\begin{array}{l}1 \text { forested } \\
\text { site, } 2 \\
\text { residential } \\
\text { sites with } \\
\text { trees and } \\
\text { without } \\
\text { trees }\end{array}$ & $9-37$ & TCC & $\begin{array}{l}\text { An extensive shading trees dropped } \\
\text { temperature more than a few green canopy } \\
\text { cover. } 1^{\circ} \mathrm{C} \text { cooling effect in residential site } \\
\text { with tree compare to the one without tree } \\
\text { illustrated the effect of trees on air } \\
\text { temperature. }\end{array}$ \\
\hline
\end{tabular}


Environment, Earth and Ecology Vol. 1 No. 1 (2017), 5-32

Armaghan Ahmadi Venhari et al.

\begin{tabular}{|c|c|c|c|c|c|}
\hline Ref & City & Type & $\begin{array}{l}\text { Size } \\
\text { (ha) }\end{array}$ & $\begin{array}{l}\text { Studied } \\
\text { index }\end{array}$ & Results \\
\hline $\begin{array}{l}\text { (Shashua- } \\
\text { Bar and } \\
\text { Hoffman } \\
\text { 2000) }\end{array}$ & $\begin{array}{l}\text { Tel Aviv, } \\
\text { Israel }\end{array}$ & 11 Streets & & $\begin{array}{l}\text { TCC, Tr, } \\
\text { CL }\end{array}$ & $\begin{array}{l}\text { The average cooling effect equaled to } 3 \mathrm{~K} \text {. } \\
\text { Shading of trees calculated by PSA is an } \\
\text { important factor in GCI. Although climate, } \\
\text { urban geometry, tree characteristics and } \\
\text { traffic were other effective factors. }\end{array}$ \\
\hline $\begin{array}{l}\text { (Lu et al. } \\
\text { 2012) }\end{array}$ & $\begin{array}{l}\text { Chongqing, } \\
\text { China }\end{array}$ & 4 parks & $\begin{array}{l}4.5- \\
36.5\end{array}$ & $\begin{array}{l}\text { SI, ShI, } \\
\text { TCC }\end{array}$ & $\begin{array}{l}\text { The area of the park as the main factor } \\
\text { effected on heat mitigation. In shape index, } \\
\text { rounder parks are more effective. }\end{array}$ \\
\hline $\begin{array}{l}\text { (Ng et al. } \\
2012)\end{array}$ & Hong Kong & $\begin{array}{l}9 \text { green } \\
\text { areas }\end{array}$ & & TCC & $\begin{array}{l}33 \% \text { green coverage decreased air } \\
\text { temperature about } 1 \mathrm{~K}\end{array}$ \\
\hline
\end{tabular}

\section{Surface or radiant temperature}

In addition to studies which were focused on air temperature to investigate the effectiveness of green spaces in cities, some studies considered surface temperature or radiant temperature. In the study of surface temperature, remote sensing data has been applied most of the time. Since the 1970s, images from multispectral scanner systems (MSS) no longer came from airplanes but from satellites. Satellites can cover a larger area of land and can monitor areas. In early research, MSS data were used by Saito (Saito et al. 1991), and by Wilmers (Wilmers 1991). Aster data is another satellite`s data which is applied to assess land surface temperature, reflection, and elevation. Yan (Yan 2006) and Hamada et al. (Hamada and Ohta 2010) implemented this data to indicate the GCI of parks. Today, Landsat and NOAA are effective sources of information and because of their infrared sensors are used for determining surface temperature (Kawashima 1991). In most of the recent studies, Landsat data was applied because of its appropriate resolution. In addition to surface temperature, also the normalized difference vegetation index (NDVI) can be derived from the satellite data. This NDVI represents vegetation density as another way to calculate the cover ratio.

In research by Nichol (Nichol 1996), the mean surface temperature of the canopy of trees, obtained from Landsat's hematic mapper, was 7.8 and $5.1 \mathrm{~K}$ cooler than that of concrete and grass surfaces respectively. Field measurements also showed that the air temperature below the canopy was 1.5-2 K cooler than in the surrounding areas. Feyisa et al. (2014) applied a linear mixed-effects model and illustrated a significant negative correlation between urban green space and surface temperature. They observed a maximum of $6.7 \mathrm{~K}$ in surface temperature reduction (Feyisa et al. 2014). Similar studies reported that the vegetation effect on surface temperatures exceeded around $7 \mathrm{~K}$ (Wilmers 1991). In a study in China, Kong (2014) showed a $0.83 \mathrm{~K}$ surface temperature reduction due to $10 \%$ increase in the vegetated area (Kong et al. 2014). Based on the correlation between vegetated area and surface temperature, Gillies and Carlson suggested a "triangular" method that couples soil -vegetation atmosphere transfer (SVAT). This approach can estimate microclimate changes based on changing land use (Gillies and Carlson 1995). Most of the studies about the effect of green spaces on surface temperature are on a large scale including whole cities. In these researchers, urban forests, green space areas and urban canyons have been compared with built environments. The land use and its effect on surface temperature were the main focus of these studies.

\section{Temporal variation}

The cooling effect of vegetation on air temperature and surface temperature is different day by day and time by time. Hamada et al. (Hamada and Ohta 2010) investigated seasonal variations of the difference in air temperature between an urban green area and its surroundings in Nagoya, Japan. They concluded that this difference was larger in summer than in winter and that in summer it was larger during the day than at night whereas in winter it was larger during the night than during the day. In a 
Environment, Earth and Ecology Vol. 1 No. 1 (2017), 5-32

Armaghan Ahmadi Venhari et al.

recent review of 17 studies on the nocturnal cooling island effect of parks by Skoulika(Skoulika et al. 2014) (2014), temperature differences of between 0.5-10 K were reported. Another review of seven studies by Bowler (Bowler et al. 2010) (2010) reported that the average nocturnal park temperatures were about $1.15^{\circ} \mathrm{C}$ below the temperatures in the surroundings of the park. In almost every season, the surface temperature cooling effect is generally higher during the day than at night (Wilmers 1991), which is not true for the air temperature cooling effect. There is evidence showing that in winter the air temperature in forests and grasslands is higher than in urban built-up areas (Chen et al. 2014).

Tab. 2 Studies on the impact of urban greening on air temperature.

\begin{tabular}{|c|c|c|c|c|c|}
\hline Ref & City & Type & Size & $\begin{array}{l}\text { Studied } \\
\text { index }\end{array}$ & Results \\
\hline $\begin{array}{l}\text { (Cao et al. } \\
2010)\end{array}$ & $\begin{array}{l}\text { Nagoya, } \\
\text { Japan }\end{array}$ & $\begin{array}{l}92 \\
\text { parks }\end{array}$ & $\begin{array}{c}0.1-41 \\
9\end{array}$ & SI, ShI & $\begin{array}{l}\text { Cooling intensity has a significant } \\
\text { relationship with size and shape of parks } \\
\text { and surface temperature. Grass has a } \\
\text { negative impact on GCI. }\end{array}$ \\
\hline $\begin{array}{l}\text { (Vailshery et } \\
\text { al. 2013) }\end{array}$ & $\begin{array}{l}\text { Bangalore, } \\
\text { India }\end{array}$ & Street & & TCC & $\begin{array}{l}27.5 \text { reduction in surface temperature in } \\
\text { street segments with shadowing trees }\end{array}$ \\
\hline $\begin{array}{l}\text { (Kjelgren } \\
\text { and } \\
\text { Montague } \\
\text { 1998) }\end{array}$ & Seattle, US & $\begin{array}{l}\text { Green } \\
\text { area }\end{array}$ & & LU & $\begin{array}{l}\text { Trees over asphalt had consistently higher } \\
\mathrm{T} \text { than those over turf }\end{array}$ \\
\hline $\begin{array}{l}\text { (Ca et al. } \\
1998)\end{array}$ & $\begin{array}{l}\text { Tokyo, } \\
\text { Japan }\end{array}$ & 1park & 60 & LU & $\begin{array}{l}\text { The cooling effect of the park was } \\
\text { intensified in the afternoon because grass } \\
\text { surface temperature became cool sooner } \\
\text { than concert and asphalt. }\end{array}$ \\
\hline $\begin{array}{l}\text { (Feyisa et al. } \\
\text { 2014) }\end{array}$ & $\begin{array}{l}\text { Addis } \\
\text { Ababa, } \\
\text { Ethiopia }\end{array}$ & 1 park & 22.3 & ShI, TCC & $\begin{array}{l}\text { A positive relationship between surface } \\
\text { temperature and NDVI and a negative } \\
\text { relationship between surface temperature } \\
\text { and shape index were conducted. }\end{array}$ \\
\hline $\begin{array}{l}\text { (Hamada et } \\
\text { al. 2013) }\end{array}$ & $\begin{array}{l}\text { Nagoya, } \\
\text { Japan }\end{array}$ & $\begin{array}{l}\text { Urban } \\
\text { forest }\end{array}$ & 147 & $\mathrm{LU}$ & $\begin{array}{l}\text { Based on surface temperature, } \\
\text { commercial areas interrupted the GCI } \\
\text { while other land uses are extended it. }\end{array}$ \\
\hline $\begin{array}{l}\text { (Kong et al. } \\
\text { 2014) }\end{array}$ & $\begin{array}{l}\text { Nanjing, } \\
\text { China }\end{array}$ & $\begin{array}{l}\text { Urban } \\
\text { green } \\
\text { areas }\end{array}$ & & $\begin{array}{l}\text { SI, } \quad \text { TCC, } \\
\mathrm{AI}^{1}\end{array}$ & $\begin{array}{l}\text { By } 10 \% \text { increasing plant area, the } \\
\text { surface temperature dropped about } 0.83 \\
{ }^{\circ} \mathrm{C} \text {. }\end{array}$ \\
\hline $\begin{array}{l}\text { (Weng et al. } \\
\text { 2004) }\end{array}$ & $\begin{array}{l}\text { Indianapoli } \\
\mathrm{s} \text {, Marion }\end{array}$ & $\begin{array}{l}\text { Urban } \\
\text { green } \\
\text { area }\end{array}$ & & TCC & $\begin{array}{l}\text { NDVI affected surface temperature } \\
\text { significantly. }\end{array}$ \\
\hline $\begin{array}{l}\text { (Wilmers } \\
\text { 1991) }\end{array}$ & $\begin{array}{l}\text { Hannover, } \\
\text { Germany }\end{array}$ & $\begin{array}{l}\text { Urban } \\
\text { green } \\
\text { area }\end{array}$ & & TCC, BG & $\begin{array}{l}\text { The vegetation effect on surface } \\
\text { temperatures exceeded around } 7 \mathrm{~K} \text {. }\end{array}$ \\
\hline $\begin{array}{l}\text { (Nichol } \\
1996)\end{array}$ & Singapour & $\begin{array}{l}\text { Urban } \\
\text { green } \\
\text { area }\end{array}$ & & LU, TCC & $\begin{array}{l}\text { The surface temperature of tree canopy } \\
\text { cover was } 7.8 \text { and } 5.1 \mathrm{~K} \text { cooler than that } \\
\text { of concrete and grass surfaces } \\
\text { respectively. }\end{array}$ \\
\hline
\end{tabular}

$\mathrm{AI}^{1}=$ Aggregation Index

\section{Thermal comfort}

Because planted areas in the city play an important role in reducing air and surface temperature, their effect on thermal comfort and perception is undeniable. Temperature equivalent perception (TEP) (Monteiro and Alucci 2009), discomfort index (DI) (Thorn 1959), Physiological Equivalent 
Temperature (PET) (Höppe 1999), Predicted Mean Vote (PMV) (Jendritzky 1990) are some of the human biometeorological methods which are used to represent outdoor thermal comfort. When calculating these variables, meteorological factors like air temperature, surface temperature, wind speed, humidity and short-wave and long-wave irradiance are applied (Akbari and Taha 1992); as such, they can give a comprehensive thermal view. Several research projects have focused on the perception of the cooling effect of vegetated areas. In a study in Sao Paolo, the reduction in PET by greening streets was up to $12 \mathrm{~K}$ (Spangenberg et al. 2008). A similar study by Toudert and Mayer showed this reduction to be above $20 \mathrm{~K}$ (Ali-Toudert and Mayer 2007). Yang et al. (2011) evaluated different urban design strategies for summer time. They concluded that adding dense trees above pavement can reduce PET up to $20 \mathrm{~K}$ which is $5 \mathrm{~K}$ more than when adding dense trees above a grass lawn (Yang et al. 2011). In another study in Brazil, TEP was applied to show the thermal comfort conditions around the building and below shading trees. This research emphasized the role of trees especially in low-rise districts (Johansson et al. 2013).

Tab. 3 Studies on the impact of urban greening on pedestrian thermal comfort.

\begin{tabular}{|c|c|c|c|c|c|}
\hline Ref & City & Type & Size & $\begin{array}{l}\text { Studied } \\
\text { index }\end{array}$ & Results \\
\hline $\begin{array}{l}\text { (Klemm et } \\
\text { al. 2015) }\end{array}$ & $\begin{array}{l}\text { Utrecht, } \\
\text { NL }\end{array}$ & 13 Park & $\begin{array}{l}0.93- \\
22.08\end{array}$ & $\begin{array}{l}\text { SI, TCC, } \\
\text { CL, UG }\end{array}$ & $\begin{array}{l}1.9 \mathrm{~K} \text { reduction in PET in parks in } \\
\text { compare with the city center and } 5 \mathrm{~K} \text { in } \\
\text { compare with surrounding grasslands } \\
\text { during the hottest period of the day. }\end{array}$ \\
\hline $\begin{array}{l}\text { (Georgi and } \\
\text { Dimitriou } \\
\text { 2010) }\end{array}$ & $\begin{array}{l}\text { Chania, } \\
\text { Greece }\end{array}$ & Park & 6 & SI, UG & $\begin{array}{l}\text { An area of } 100 \mathrm{~m} 2 \text { with } 8 \text { trees in } 5 \mathrm{~m} \\
\text { distance from each other provide } \\
\text { desirable thermal comfort in the year. }\end{array}$ \\
\hline $\begin{array}{l}\text { (Johansson } \\
\text { et al. 2013) }\end{array}$ & $\begin{array}{l}\text { Sao Paulo, } \\
\text { Brazil }\end{array}$ & $\begin{array}{l}6 \quad \text { Urban } \\
\text { tissues }\end{array}$ & & TCC & $\begin{array}{l}10^{\circ} \mathrm{C} \text { difference in TEP between a bare } \\
\text { soil, wooded area, and a complete cover } \\
\text { of tree canopy was recorded. In streets } \\
\text { with low rise building, adding shading } \\
\text { trees was an important cooling strategy. }\end{array}$ \\
\hline $\begin{array}{l}\text { (Spangenber } \\
\text { g et al. 2008) }\end{array}$ & $\begin{array}{l}\text { Sao Paulo, } \\
\text { Brazil }\end{array}$ & $\begin{array}{l}\text { A park, a } \\
\text { square, and a } \\
\text { street canyon }\end{array}$ & & TCC & $\begin{array}{l}\text { The denser the tree canopy (higher LAI } \\
\text { and LAD) decreased PET up to } 12^{\circ} \mathrm{C} \text {. }\end{array}$ \\
\hline $\begin{array}{l}\text { (Ali-Toudert } \\
\text { and Mayer } \\
\text { 2007) }\end{array}$ & & $\begin{array}{l}5 \quad \text { Urban } \\
\text { streets }\end{array}$ & & UG,TCC & $\begin{array}{l}\text { The importance of urban streets direction } \\
\text { and its sky view factor in PET. }\end{array}$ \\
\hline $\begin{array}{l}\text { (Charalampo } \\
\text { poulos et al. } \\
2013)\end{array}$ & $\begin{array}{l}\text { Athens, } \\
\text { Greece }\end{array}$ & $\begin{array}{l}6 \text { sites at } \\
\text { university }\end{array}$ & & TCC & $\begin{array}{l}8.7^{\circ} \mathrm{C} \text { reduction in PET by less } \mathrm{SVF} \text { and } \\
\text { dense green coverage. }\end{array}$ \\
\hline $\begin{array}{l}\text { (Correa et al. } \\
\text { 2012) }\end{array}$ & $\begin{array}{l}\text { Mendoza, } \\
\text { Argentina }\end{array}$ & $\begin{array}{l}9 \quad \text { urban } \\
\text { streets }\end{array}$ & & $\begin{array}{l}\text { UG, } \\
\text { TCC, SpI }\end{array}$ & $\begin{array}{l}\text { A continuous green corridor along the } \\
\text { street with Platanus acerifolia increased } \\
\text { thermal comfort. }\end{array}$ \\
\hline $\begin{array}{l}\text { (Lin et al. } \\
2010)\end{array}$ & Taiwan & $\begin{array}{l}\text { University } \\
\text { campus }\end{array}$ & & TCC & $\begin{array}{l}\text { Increasing SVF in summer and } \\
\text { decreasing SVF in winter effected on PET } \\
\text { and caused discomfort. }\end{array}$ \\
\hline $\begin{array}{l}\text { (Yan et al. } \\
\text { 2012) }\end{array}$ & $\begin{array}{l}\text { Beijing, } \\
\text { China }\end{array}$ & $\begin{array}{l}8 \text { City and } \\
\text { suburb } \\
\text { districts }\end{array}$ & & SpI, TCC & $\begin{array}{l}\text { The tree canopy characteristics such as } \\
\text { leaf area index and canopy coverage are } \\
\text { important factor in shadowing urban } \\
\text { space and decrease diurnal discomfort } \\
\text { index (DI) }\end{array}$ \\
\hline
\end{tabular}


Environment, Earth and Ecology Vol. 1 No. 1 (2017), 5-32

Armaghan Ahmadi Venhari et al.

\begin{tabular}{|c|c|c|c|c|c|}
\hline Ref & City & Type & Size & $\begin{array}{l}\text { Studied } \\
\text { index }\end{array}$ & Results \\
\hline $\begin{array}{l}\text { (Yang et al. } \\
\text { 2011) }\end{array}$ & $\begin{array}{l}\text { Shanghai, } \\
\text { china }\end{array}$ & $\begin{array}{l}2 \text { high-rise } \\
\text { residential } \\
\text { quarters }\end{array}$ & & TCC, LU & $\begin{array}{l}\text { Adding shadowing tree with } \mathrm{LAI}=6.4 \\
\text { over the lawn and hard pavement } \\
\text { decreased PET up to } 15^{\circ} \mathrm{C} \text { and } 20^{\circ} \mathrm{C} \\
\text { respectively. }\end{array}$ \\
\hline
\end{tabular}

In conclusion, adding shaded trees to urban areas has a cooling effect and especially in summer can help reduce energy consumption. The effect of greening cities on air temperature is less than on surface temperature and on thermal comfort. According to a study by Schwardz et al.(Schwarz et al. 2012), air temperature and surface temperature positively correlated. The difference, however, in the surface temperature between green areas, built areas and bare areas was more than in air temperature. Due to their data types and the information content, this difference is explainable. For air temperature, shadow, evaporation and optical properties are more effective, while for surface temperature thermal storage and admittance play important roles. In the human biometeorological models, different meteorological factors are applied. This overall view can thus describe the thermal comfort of people in urban spaces and is a better index to show the effect of green areas and people's behavior.

\subsection{Cooling extension}

The second parameter of the cooling effect is the cooling extension. One of the major questions is what distance the cooling effect was observed. Several studies were focused on identifying this extension (Declet-Barreto et al. 2013; Lin et al. 2015; Vanos et al. 2012; Wardoyo et al. 2012). Skoulika (Skoulika et al. 2014) in 2012 indicated that the air temperature gradient of a medium size urban park in Athens was between 0.2 and $1.4 \mathrm{~K}$ per $100 \mathrm{~m}$. Almost similar results were reported by Lindqvist (Lindqvist 1992) for Gothenburg Sweden (0.33 K per $100 \mathrm{~m}$ ), and by Lee (Lee et al. 2009) (2 K per $100 \mathrm{~m}$ ) in Seoul, Korea. Shashua (Shashua-Bar and Hoffman 2000)(2000) concluded that the cooling effect will decrease $1.4 \%$ every $10 \mathrm{~m}$. Reported distances of the thermal impact of green areas on their surroundings differ among studies ranging between $15 \mathrm{~m}$ as found by Saito (Saito et al. 1991) (1991) to $2000 \mathrm{~m}$ as found by Jauregui (Jauregui 1991) (1990/91). The size of the green spaces was obviously different and in many studies this size was reported to be an important parameter determining the cooling extension (Honjo and Takakura 1991; Upmanis et al. 1998). Chen et,al.(Chen et al. 2012) in their study in China reported that parks larger than $740000 \mathrm{~m}^{2}$, decrease temperature around $1 \mathrm{~m}$ per 10 $000 \mathrm{~m}^{2}$ increase of vegetated area.

Wind direction is another significant factor which can change the range of the effect (Honjo and Takakura 1991). In comparisons between the range of the thermal effect of a park in different studies, the radius of the effect in the downwind field was reported more than in the upwind one (Fryd et al. 2011; Hamada et al. 2013). Different studies showed that the GCI extends in the direction of the prevailing wind (Ca et al. 1998; Jauregui 1991; Oke et al. 1989). Fryd (Fryd et al. 2011) (2011) indicated that topography and surrounding city structures were two factors affecting the distance of the cooling effect of green spaces on their surroundings. As increasing the height of buildings and increasing urban density can block the wind flow to the surrounding areas, these parameters play a key role in the cooling extension. Upmanis et al. (Upmanis et al. 1998) concluded that due to confinements for air circulation by the built environment around a small park in Gothenburg, Sweden, the thermal influence of this park was limited. The range of the cooling extension during the day is not similar to that during the night. Large differences between day and night were reported by Hamada (Hamada and Ohta 2010) (2010). He reported that the extension of the thermal effect of green areas was about 200-300 m at night while this effect was about 300-500 m during the day between August and October. 
Environment, Earth and Ecology Vol. 1 No. 1 (2017), 5-32

Armaghan Ahmadi Venhari et al.

Tab. 4 Studies on the cooling extension of urban greening.

\begin{tabular}{|c|c|c|c|c|c|}
\hline Ref & City & Type & Size (ha) & $\begin{array}{l}\text { Studied } \\
\text { index }\end{array}$ & Results \\
\hline $\begin{array}{l}\text { (Doick et al. } \\
\text { 2014) }\end{array}$ & $\begin{array}{l}\text { London, } \\
\text { UK }\end{array}$ & $\begin{array}{l}3 \text { Parks and } 1 \\
\text { street }\end{array}$ & $\begin{array}{l}\text { seRSW19- } \\
142\end{array}$ & $\mathrm{CL}$ & $\begin{array}{l}\text { Cooling of up to } 4{ }^{\circ} \mathrm{C} \text { with } 440 \mathrm{~m} \\
\text { cooling extension. Wind speed has } \\
\text { important role in cooling extension. }\end{array}$ \\
\hline $\begin{array}{l}(\mathrm{Ca} \text { et al. } \\
1998)\end{array}$ & $\begin{array}{l}\text { Tama, } \\
\text { Japan }\end{array}$ & 1 park & 60 & SI, CL & $\begin{array}{l}1.5^{\circ} \mathrm{C} \text { of cooling extending } 1 \mathrm{~km} \\
\text { around studied park }\end{array}$ \\
\hline $\begin{array}{l}\text { (Upmanis et } \\
\text { al. 1998) }\end{array}$ & $\begin{array}{l}\text { Goteborg, } \\
\text { Sweden }\end{array}$ & Park & 156 & SI, TCC & $\begin{array}{l}4{ }^{\circ} \mathrm{C} \text { cooling influence that extended } \\
775 \mathrm{~m} \text { around the } 156 \text { ha park. }\end{array}$ \\
\hline $\begin{array}{l}\text { (Chandler } \\
\text { 1966) }\end{array}$ & $\begin{array}{l}\text { London, } \\
\text { UK }\end{array}$ & Park & 142 & CL & $\begin{array}{l}\text { The } 3{ }^{\circ} \mathrm{C} \text { cooling effect to } 200 \mathrm{~m} \\
\text { around Hyde Park }\end{array}$ \\
\hline $\begin{array}{l}\text { (Watkins et } \\
\text { al. 2002) }\end{array}$ & $\begin{array}{l}\text { London, } \\
\text { UK }\end{array}$ & Park & 50 & & $\begin{array}{l}\text { Maximum } 1.1{ }^{\circ} \mathrm{C} \text { of cooling } \\
\text { intensity with } 200 \text { to } 400 \mathrm{~m} \text { cooling } \\
\text { extension. }\end{array}$ \\
\hline $\begin{array}{l}\text { (Cao et al. } \\
2010)\end{array}$ & $\begin{array}{l}\text { Nagoya, } \\
\text { Japan }\end{array}$ & 92 parks & 41.9 & SI, ShI & \\
\hline $\begin{array}{l}\text { (Oliveira et } \\
\text { al. 2011) }\end{array}$ & $\begin{array}{l}\text { Lisbon, } \\
\text { Portugal }\end{array}$ & Garden & 0.24 & $\mathrm{UG}, \mathrm{CL}$ & $\begin{array}{l}\text { With maximum } \Delta \mathrm{Ta} \text { and } \Delta \mathrm{Tmrt} \\
\text { equal to } 6.9^{\circ} \mathrm{C} \text { and } 39.2 \text { respectively } \\
\text { and maximum extension around } \\
300 \mathrm{~m} \text {. }\end{array}$ \\
\hline $\begin{array}{l}\text { (Georgi and } \\
\text { Dimitriou } \\
2010)\end{array}$ & $\begin{array}{l}\text { Chania, } \\
\text { Greece }\end{array}$ & Park & 6 & SI, UG & $\begin{array}{l}\text { Maximum cooling extension equal } \\
\text { to } 100 \mathrm{~m} \text { around the park }\end{array}$ \\
\hline $\begin{array}{l}\text { (Jauregui } \\
\text { 1991) }\end{array}$ & $\begin{array}{l}\text { MexicoCit } \\
\text { y, Mexico }\end{array}$ & Park & 525 & SI, UG & $\begin{array}{l}\text { Minimum cooling effect } 3^{\circ} \mathrm{C} \text { and its } \\
\text { effect were observed to } 2000 \mathrm{~m}\end{array}$ \\
\hline $\begin{array}{l}\text { (Saito et al. } \\
\text { 1991) }\end{array}$ & $\begin{array}{l}\text { Kumamoto } \\
\text {, Japan }\end{array}$ & Park & $0.24-2.25$ & TCC & $\begin{array}{l}\text { The cooling effect around } 15-20 \mathrm{~m} \\
\text { was recorded. }\end{array}$ \\
\hline $\begin{array}{l}\text { (Oke et al. } \\
1989)\end{array}$ & $\begin{array}{l}\text { Montreal, } \\
\text { Canada }\end{array}$ & Park & 38 & & $\begin{array}{l}400 \mathrm{~m} \text { cooling extension was } \\
\text { detected }\end{array}$ \\
\hline
\end{tabular}

\section{Main effective indexes on heat mitigation}

In the reviewed research papers, different indexes were considered that affect the cooling effect of vegetated areas in cities. After reviewing the literature, the most common indexes in studies have been divided into two categories: internal indexes and external indexes. Internal indexes are about the characteristics of the green space itself such as its area, shape, coverage and species of greenery while external indexes present the factors arising from the climate and from the neighborhood around the green area which alter the cooling effect of this green area. The number of studies on each index is presented in table 5 .

Tab. 5 The number of studies on each index.

\begin{tabular}{|c|c|c|c|c|c|c|c|c|}
\hline \multirow{3}{*}{$\begin{array}{l}\text { Studied } \\
\text { Index }\end{array}$} & \multicolumn{4}{|c|}{ Internal indexes } & \multicolumn{4}{|c|}{ External indexes } \\
\hline & \multirow{2}{*}{$\begin{array}{c}\text { Size } \\
\text { Index } \\
(\mathrm{SI})\end{array}$} & \multirow{2}{*}{$\begin{array}{l}\text { Shape } \\
\text { Index } \\
\text { (ShI) }\end{array}$} & \multirow{2}{*}{$\begin{array}{c}\text { Tree } \\
\text { Canopy } \\
\text { Cover } \\
\text { (TCC) }\end{array}$} & \multirow{2}{*}{$\begin{array}{c}\text { Species } \\
\text { Index } \\
(\mathrm{SpI})\end{array}$} & \multirow{2}{*}{$\begin{array}{c}\text { Climate } \\
\text { (CL) }\end{array}$} & \multicolumn{3}{|c|}{ The Adjacent Urban Fabric (AUF) } \\
\hline & & & & & & $\begin{array}{c}\text { Land } \\
\text { use } \\
\text { (LU) }\end{array}$ & $\begin{array}{c}\text { Urban } \\
\text { Geometry } \\
\text { (UG) }\end{array}$ & $\begin{array}{c}\text { Traffic } \\
\text { (Tr) }\end{array}$ \\
\hline $\begin{array}{l}\text { Number } \\
\text { of studies }\end{array}$ & 26 & 7 & 28 & 21 & 8 & 7 & 14 & 3 \\
\hline
\end{tabular}




\subsection{Internal indexes}

\section{Size index (SI)}

The size of the green area is one of the important issues under discussion. Several studies showed that both the cooling intensity and the cooling extension were affected by the size of the vegetated area (Chen et al. 2012; Feyisa et al. 2014; Spronken-Smith 1994).

With regard to cooling intensity, size index plays an important role. In a quantitative evaluation of urban park cool island factors, Lu et al.(Lu et al. 2012) mentioned that the main factor was the area of the park. They compared 4 green spaces in China with sizes from 4.5 to 36.7 ha and showed that the $\mathrm{GCI}$ of the largest one was around $2 \mathrm{~K}$ cooler than of the smallest one. In other research from Sweden, Upmanis (Upmanis et al. 1998) found the cooling intensity of 3 parks, 2.4 ha, 3.6 ha and 156 ha, to be $1.7,2.6$ and $5.9^{\circ} \mathrm{C}$ respectively. This cooling intensity was not similar in all studies and increasing the size of the park sometimes had a smaller effect. The park's characteristics and the climate can be two important factors which may have affected the results. Chang et al (Chang et al. 2007) indicated that large parks had usually a lower temperature than small ones; they demonstrated that there was not a linear correlation between cooling intensity and size index, though. They classified 61 parks in Taipei into three classes: large, medium and small with corresponding areas " $>1$ ha", " $0.5-1$ ha" and " $<0.5$ ha". Their results showed that at noon in summer the parks larger than 3 ha were consistently cooler than their surroundings and the smaller parks were not always. All the parks that were warmer than their surroundings were smaller than 2 ha. During the nights in summer and at noon in winter, even 7 ha - parks became a local heat island. They deduced that smaller parks have less shadow and more paved surfaces which trap heat and increase temperature. In contrast, Bacci et al.(Bacci et al. 2003) reported a linear correlation between GCI and size index. They compared 6 green spaces in Italy and concluded that the cooling intensity both during the day and during the night significantly related to green area size. Although even small green spaces could decrease temperature, they found evidence showing that a park size of more than 2 ha was more effective. Similar results were found by Barradas (Barradas 1991) who analyzed 5 parks in Mexico City with areas between 1.9 to 9.9 ha. He also reported a linear correlation between cooling intensity and park area. Chen et.al(Chen et al. 2012), using Landsat Thematic Mapper data for 10 parks in China, reported that for the parks in which more than $69 \%$ of the area was green and which had a length-to-width ratio close to 1 there was a linear relationship between average cooling intensity and the size of the green spaces. There are also a few studies that illustrate that even small vegetated areas have a certain degree of cooling intensity. Georgi (Georgi and Dimitriou 2010) suggested that an area of $100 \mathrm{~m}^{2}$ with eight trees with a distance of $5 \mathrm{~m}$ between them could be helpful to lower the temperature.

Researchers report different results concerning the effect of size index on the cooling extension. From his study of 3 parks, 2.4 ha, 3.6 ha and 156 ha, Upmanis (Upmanis et al. 1998)reported that the size of the park affected the cooling extension which reached to $1175 \mathrm{~m}$ around the largest park. The results of Chen et al's (Chen et al. 2012) study showed a nonlinear relationship between cooling distance and green area. They indicated that the parks smaller than $10566 \mathrm{~m}^{2}$ had no significant cooling effect on their surroundings and that the parks with an area of 10566 and $740000 \mathrm{~m}^{2}$ and a length-to-width ratio close to 2 did have a remarkable cooling extension. In a recently published paper, Lin (2015), based on a field study and on remote sensing, determined the cooling extension of parks to vary from $35 \mathrm{~m}$ to $840 \mathrm{~m}$. In this study, larger parks were more effective to extend GCI to their surroundings (Lin et al. 2015). Most studies found similar results concerning the direct relationship between cooling distance and the area of green spaces in cities (Hamada and Ohta 2010; Yu and Hien 2006). In contrast, there also are studies which recommend small parks. $\mathrm{Ca}$ (Ca et al. 1998) illustrated that the GCI of a small park on surface temperature with an area $0.6 \mathrm{~km}^{2}$ was $1.5 \mathrm{~K}$ and it extended to $1 \mathrm{~km}$ downwind in a 
commercial district. Saito et al. (Saito et al. 1991), and Watkins et al. (Watkins et al. 2002) proved that even small parks had a cooling extension when it comes to surface temperature. A network of small parks in sufficiently close distance to each other as a strategy to mitigate a high temperature in the city has also been suggested by researchers (Givoni 1972; Honjo and Takakura 1991). Based on simulations, Honjo et al.(Honjo and Takakura 1991) reported that the optimum interval between green areas was $200 \mathrm{~m}$ in the downwind field direction if the width of the vegetated area was 300-700 m. As a result, the studies, which emphasized the cooling extension of small parks, studied surface temperature from satellite images or applied simulations; field studies, though, showed that the extension effect of small parks on air temperature was negotiable.

In conclusion, most of the field studies approved that increasing the size enhances the cooling intensity and cooling extension. There is some evidence that even small green spaces can have a cooling effect. However, the cooling intensity and cooling distance of green areas smaller than 2 ha do not seem enough for the meso-climate. A checkerboard of medium to large green spaces in each district for heat mitigation in a meso-climate and small green spaces in neighborhoods with the sufficiently short distance between them could be useful in influencing the micro-climate.

\section{Shape index (ShI)}

Shape index is the perimeter-to-area ratio that quantifies the geometric complexity of green areas in cities. In many studies about landscape metrics, one of the main indexes is the shape index (Aithal and Sanna 2012; Fan and Myint 2014; McGarigal 2002). The landscape shape index (LSI) was a term introduced in 1975 by Patton (Patton 1975) for the first time which describes the degree of compactness of a patch of land. Fan (2014) applied satellite images to calculate the shape index and suggested it as a factor in landscape metrics (Fan and Myint 2014). This factor was explained as being an important factor for cooling intensity and cooling distance (Cao et al. 2010). Although many more studies focused on size index, there have been studies which proved that shape index helps explaining thermal mitigation. Shape index (ShI) or landscape shape index (LSI) are calculated with different formulas. Cao et al. (Cao et al. 2010) who studied 92 parks in Nagoya, Japan, focused on the effect of size and shape on surface temperature. They used below formula to calculate LSI:

$$
L S I=\frac{P_{t}}{2 \sqrt{\pi * A}}
$$

Where $\mathrm{P}_{\mathrm{t}}$ is the perimeter around the green space, its circumference, and $\mathrm{A}$ is its area. LSI equals to 1.00 and 1.13 for the circle and square shapes respectively. Coa et al. reported LSI values from 1.01 to 5.76 for the parks presented in figure 2 (Fig. 2).

A study (Ramachandra et al. 2012) in Bangalore applied LSI to describe urban dynamics and analyze urban patterns. The result illustrated that LSI was close to one in the city center and that higher LSI was calculated for city developments from 2010. In another study on the more useful LSI in GCI, Feyisa (Feyisa et al. 2014) concluded that parks with a higher shape index had different behavior with respect to cooling distance and cooling intensity. For these green spaces the range of the effect was larger; in contrast, their cooling intensity was less. Thus, when the shape of a vegetated area was closer to a circle, its cooling intensity was higher than of other shapes and when the shape was more irregular, the distance of the cooling effect was larger. Similar results were obtained from six typical parks in Chongqing, China, by Lu et al. (Lu et al. 2012). They indicated a negative correlation between cooling intensity and shape index and suggested that the circular shape is the best shape for a high cooling intensity.

From these study, it can conduct that depending on the exact goals in each part of the city different shapes for green areas will be useful. For instance, in the districts of a city in which a heat island is detected and the cooling intensity is more important, like in a city center, a regular shape close to a 
circle is suggested. In other districts, in order to increase the cooling distance and mitigate high temperatures in a larger area, like neighborhoods, irregular forms will be more effective.

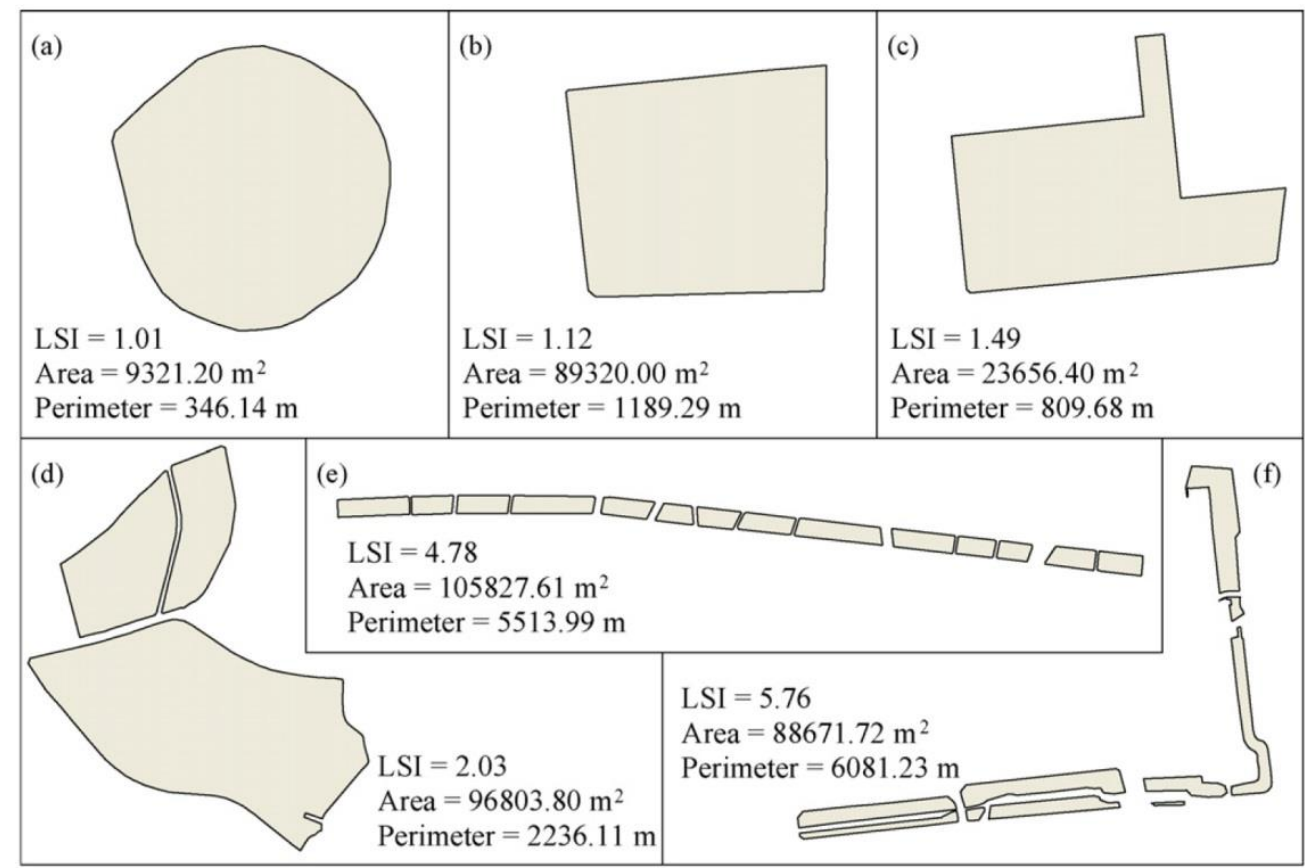

Fig. 2 The LSI values of different park shapes (Cao et al. 2010).

\section{Tree Canopy Cover(TCC)}

"Tree Canopy Cover" (TCC) can be defined as the area of ground covered by the extension of plant foliage (Jennings et al. 1999). TCC is a term widely used in forest research and management (Fiala et 1. 2006) and sometimes also referred to as "Forest Canopy Cover" (FCC) in some large-scale researches (Hamada and Ohta 2010). Because TCC can give useful information about the area covered by trees and their effect on temperature, this term was also applied in thermal comfort and energy efficiency studies. Although size index and shape index are two important factors for the thermal effect of greenery, a clarifying factor that shows how much of a corridor or patch of land is covered by greenery is necessary. Sometimes, although the size index is high, the GCI is not as much as expected. One of the reasons, in that case, may be low tree canopy cover or a few shadowing trees in that particular green patch (Chang et al. 2007). Many studies approved that increasing the canopy cover was a cost-effective way to decrease the temperature, to mitigate urban heat island effect and to reduce energy consumption (Feyisa et al. 2014; McPherson and Simpson 2003; Rosenfeld et al. 1998). McPherson et al. (McPherson and Simpson 2003) applied aerial photographs of California to calculate the tree canopy cover and to simulate energy use. They showed that adding shading trees and increasing green canopy cover in summer can reduce energy consumption by about $10 \%(5,190 \mathrm{MW})$ by influencing the micro- and meso-climate. A similar study for Los Angeles picked out shading trees as a means of heat island mitigation and called these a strategy of cool communities (Rosenfeld et al. 1998). Hamada et al. (Hamada and Ohta 2010), finally, illustrated that by increasing forest-cover ratio by $10 \%$ a $0.43 \mathrm{~K}$ decline in temperature was recorded at 15:00. In this study, the GCI was more significant than in Katayama et al.'s study, which reported a $2 \mathrm{~K}$ reduction in case of a $100 \%$ increase in TCC.

Tree canopy cover in order to prevent solar radiation from passing through trees has an important effect on GCI. Huang (Huang et al. 1990) reported that only 10 to 30 percent of the energy of the sun penetrates through the foliage to the ground below a tree and that the remaining part is absorbed by the 
leaves for photosynthesis or reflected back into the sky. In addition, surface materials by their heat retention and emission affect surface and air temperature (Liu et al. 2012; Zhan et al. 2012), thus the canopy cover is an important index for the cooling effect of green areas. In addition, canopy cover can reduce the wind speed in urban space. Another study concluded that by a $10 \%$ increase of canopy cover the wind speed increased by $8 \%$ (Yang et al. 2013).

There are different ways to calculate canopy cover: the normalized difference vegetation index (NDVI), green coverage ratio (GCR), leaf area index (LAI), vegetated sky view factor and the partially shaded area (PSA) are the common ones.

To calculate NDVI, temperature remote sensing data was applied most of the time. In a recently published paper, Feyisa et al. (Feyisa et al. 2014) found a negative correlation between air temperature and canopy cover defined by NDVI ( $\mathrm{p}<0.001)$. They found that every percent (point) increase in canopy cover has a cooling effect of around 0.02K. Buyadi et al. (Buyadi et al. 2013) in 2013 compared green areas in Shah Alam, Selangor, in the year 1991 and 2009 and applied NDVI to find its effects on land surface temperature (LST). They concluded that by decreasing NDVI by about $17.48 \%$, the range of radiant temperature changed from $25.8^{\circ} \mathrm{C}-30.8^{\circ} \mathrm{C}$ to $24.0^{\circ} \mathrm{C}-38.0^{\circ} \mathrm{C}$. This means the effect of NDVI on surface temperature is more than on air temperature. Besides, both of these temperatures are important in perceptual temperature and thermal comfort.

Srivanit et al.(Srivanit and Kazunori 2011), who studied urban morphology indicators and their effects on urban climate, reported that green coverage ratio (GCR) was one of the most important indicators. They defined GCR as the percentage of green coverage or the ratio of the area of shading trees to the area of the land. In their study, a significant negative correlation (64.9\%) between GCR and average daytime summer air temperature was found.

Leaf area index (LAI), which is the ratio of surface area of the leaves to the ground area, is another indicator representing plant canopy cover (Kumar and Kaushik 2005; Takakura et al. 2000). Chen (Chen and Wong Nyuk 2006) used LAI to study vegetative canopies. His results showed that a higher density of plants caused a lower ambient temperature. For Terre Haute, Indiana, USA, the relationship between leaf area index and surface temperature was illustrated: when the leaf area index increased to 1.0, the surface temperature dropped by $1.3^{\circ} \mathrm{C}$ (Hardin and Jensen 2007). Increasing LAI enhances evapotranspiration (Rey 1999), (Bréda and Granier 1996) of leaves which affect air temperature.

Shashua et al. (Shashua-Bar and Hoffman 2000) used the partially shaded area (PSA)to quantify tree coverage. They calculated PSA as the ratio of the shaded area of the trees to the ground area at noon. The sky view factor, SVF, is defined as the percentage of the free sky at specific locations (Oke 1987).

The sky view factor (SVF) includes vegetation and buildings which block the view towards the sky. Increasing the TCC can decrease the vegetated sky view factor and cause more shading during the day and less radiation exchange with the sky during the night. Thus a low SVF causes cooler pockets of space during daytime and cooler pockets of space at night (Svensson 2004; Yamashita et al. 1986). Yang et al. (2013) reported a significant correlation between the tree sky view factor (TVF), which is defined as the amount of sky being blocked by trees. and the urban micro-climate. They, with a special focus on wind velocity, concluded that by a decrease of $10 \%$ in the tree view factor, the wind velocity increased by a factor of 3-4 \% both during the day and at night (Yang et al. 2013). A study in Athens, Greece, found a significant correlation between the tree view factor and PET. Researchers recorded a maximum of $8.7 \mathrm{~K}$ difference in between two sites, one with and one without trees (Charalampopoulos et al. 2013). Similar results were reported for Mendoza, Argentina. That study showed that obstacles blocking the view towards the sky caused the cooling of urban areas during the day(Correa et al. 2012). Based on12 field experiments investigating outdoor thermal comfort in central Taiwan, a direct relationship between SVF and PET in winter and an inverse relationship in summer was found (Lin et al. 2010). 
In conclusion, covering urban space with shading trees is a method to control solar radiation and make cool islands in the morning. The impact of size seems to depend on the specific climate and the problem as a result of which the best TCC seems to depend on the same factors. For example in a city with hot summers and mild winters, adding more shading trees will be effective. However, in a city center with a night heat island, covering the urban spaces with trees is not an effective method.

\section{Species index (SpI)}

Because of their different thermal effects, selecting the right species for urban green spaces is important. Different anatomical and physiological characteristics cause different cooling effects (De Bruin and Jacobs 1993). There have been many studies to find which species is more effective in thermal mitigation.

The physical, chemical and biological properties of species influence the density and the shading quality of each species and as a result, affect the thermal conditions around the plants. The foliage of a tree can block 60 to $90 \%$ of the incident solar radiation (Liérbard and De Herde 2005). In addition, depending on their species, leaves can absorb up to $90 \%$ of UV radiation and a wide range of infrared radiation (Escourrou 1981). Shashua-Bar et al. (Shashua-Bar et al. 2009), after a study of seven vegetation species, illustrated that the Ficus was the most effective one. They reported that due to the envelope of the Ficus, the solar radiation penetrating through the canopy of this species was only about $5 \%$. As penetrating solar radiation and shadow have a strong impact on surface and air temperature, the thermal impact of trees is higher than of other types (Bacci et al. 2003; Cao et al. 2010; Hamada and Ohta 2010). In a recently published study, Zhang et al. (Zhang et al. 2014) categorized urban greenery into seven structural types: tree, grass, shrub, tree-shrub, shrub-grass, tree-grass, tree-grass-shrub, and studied their thermal behavior. They concluded that the combination of trees, grass and shrubs had the maximum air temperature reduction, $2.6 \mathrm{~K}$ and that grass alone had the smallest effect, 0.8-0.9 K. Similar results reported by Nichol (Nichol 1996) illustrated that grass surfaces had no significant cooling effect. In a comparison between a grassland and a woodland in Florence, Italy, in August 2008, he demonstrated that from 9 am to 9 pm the woodland was cooler than the grassland and after $9 \mathrm{pm}$ the grassland temperature dropped faster and stronger than the woodland temperature (Petralli et al. 2009). As mentioned before, midday photosynthesis and heat released from decomposition ( $\mathrm{Lu}$ et al. 2012; Potchter et al. 2006) are important in the thermal behavior of grass.

Oke (Oke et al. 1989) indicated that the leaf`s roughness and canopy cover determine the temperature drop. He compared coniferous and deciduous forests and reported that the coniferous forest had a lower albedo which led to a higher air temperature. On the other hand, Leuzinger et al. (Leuzinger et al. 2010) reported that broad-leaf species have a higher crown temperature. In similar research, Wenting (Wenting et al. 2012) showed that coniferous and broad-leaf plants were the most effective combination in summer and could decrease the temperature by $3.8 \mathrm{~K}$. On second place, the broad-leaf deciduous type had the largest cooling effect by decreasing the temperature by $3.7 \mathrm{~K}$ whereas the bamboo forest type and the coniferous type had the lowest cooling effect of around $1 \mathrm{~K}$. In a detailed study, the impact of leaf properties on temperature was studied by Lin et al. (Lin and Lin 2010). They indicated that some species of trees are more useful for thermal mitigation than others; for instance, the cooling intensity of U. Parvifolia was $2.52 \mathrm{~K}$ while that of C.Fitula was only $0.64 \mathrm{~K}$. They suggested that leaf color lightness, foliage density, leaf thickness, and leaf texture (surface roughness) are the factors of each species determining their cooling impacts. Light green, thick-leafed trees with rough leaves had a significant positive effect on decreasing the temperature. Similarly, Ehleringer (Ehleringer 1985) showed that rough-leaved plants absorbed less solar radiation and that the air temperature under their canopy was lower than in the case of smooth-leaved plants.

Another important factor in the cooling behavior of plants is their transpiration which was studied by among others Goyal (Goyal 2004) and Tuzet (Tuzet et al. 2003). Less evaporation may result in a 
lower cooling intensity. After studying plant species in Chania, Greece, Georgi (Georgi and Dimitriou 2010) reported that some species like the Ficus, with a high transpiration rate, decrease the temperature more than other species.

This literature review illustrates that most of the studies about species index have examined the cooling intensity of different kinds of vegetation. The cooling extension as the second parameter of the cooling effect, therefore, needs more study.

\subsection{External indexes}

The internal properties of the planted areas like their size, shape, green coverage and their species are important factors determining the total cooling intensity and the cooling extension. Besides, particularly the cooling extension is also influenced by the local climate (Skoulika et al. 2014; Zhang et al. 2013). Furthermore, the characteristics of the surrounding area is another important factor which influences cooling intensity and cooling extension (Jauregui 1991; Saito et al. 1991).

\section{Climate (CL)}

The importance of climate in the GCI can be seen from studies conducted in different climates. Shashua et al. (Shashua-Bar and Hoffman 2000) illustrated that not only the climate but also the microclimate plays an imperative role. They called it "the background effect".

The Köppen climate classification, which has been applied in this review, divides climates into five main groups (A, B, C, D, and E). In Groups A and B the Tropical/mega-thermal climates and Dry (arid and semi-arid) climates are included respectively. Group $\mathrm{C}$ is defined as Temperate/mesothermal climate which includes the Mediterranean, Humid subtropical and Oceanic climate. The Continental/microthermal climates and Polar and alpine climates are grouped under D and E (Peel et al. 2007). Based on this climate classification, all relevant studies have been reviewed again to draw conclusions about the effect of climate on GCI.

In comparing GCI in a different climate, the highest cooling effect of vegetated areas can be found in hot -arid climates. Based on studies, the average and minimum GCI in hot arid climates were $4.4 \mathrm{~K}$ and $2 \mathrm{~K}$ respectively. Spoken (Spronken-Smith and Oke 1998) proved that the park cool effect was stronger in hot and dry climates than in other climates. Although the cooling effect of a vegetated area is considerably larger in a hot desert than in other climates, the number of studies in hot and dry climates is, however, fairly limited. Similar limited studies in tropical climates emphasized the effect of green spaces to mitigate the urban heat island effect especially in Malaysia (Ahmad 1992; Elsayed 2012; Sani 1987). According to table 6 , most of the studies have been conducted in a temperate climate, which was divided into Mediterranean, Subtropical and Oceanic climates. The average GCI in a temperate climate was around $2.5 \mathrm{~K}$. In Mediterranean cities with dry summers and subtropical cities with warm summers the GCI is generally higher than in Oceanic climates. The GCI in continental climates is not as important as in hot-arid and tropical climates.

As a result, the effect of green spaces in heat mitigation is larger in climates with hotter summer than in other ones. However, more studies need to be done in hot-arid and tropical climates.

In conclusion, the thermal benefits of greening cities are not the same in all climates. The GCI in climates with generally a higher air temperature and with drier summers is more than in other climates. In arid and semi-arid climates, the effects of planted areas were not only limited to thermal effects, surface, and air temperature but also included increased humidity and more cool breeze. However, the number of studies in these climates are still limited. Due to lack of water in arid and semiarid cities, greening these cities is very sensitive and needs more study to find the minimum effective greenery for heat mitigation. 
Environment, Earth and Ecology Vol. 1 No. 1 (2017), 5-32

Armaghan Ahmadi Venhari et al.

Tab. 6 Studies on GCI in different climate.

\begin{tabular}{|c|c|c|c|c|c|}
\hline \multicolumn{2}{|l|}{ Group } & City (Ref) & $\begin{array}{l}\text { Ave. } \\
\text { GCI }\end{array}$ & $\begin{array}{l}\text { Max. } \\
\text { GCI }\end{array}$ & $\begin{array}{l}\text { Min. } \\
\text { GCI }\end{array}$ \\
\hline \multicolumn{2}{|c|}{ A: Tropical Climate } & $\begin{array}{lrr}\text { Kuala } & \text { Lumpur(Ahmad } & 1992 ; \\
\text { Elsayed } & 2012 ; \quad \text { Sani } & 1987) \\
\text { Bangalore } & \text { (Vailshery et al. 2013) }\end{array}$ & 3.24 & 5.6 & 1.5 \\
\hline \multicolumn{2}{|c|}{ B: Arid and Semi-arid Climate } & $\begin{array}{lr}\text { Botswana(Jonsson } & \text { 2004), } \\
\text { Tucson(Spronken-Smith } & \text { 1994), } \\
\text { Algeria(Rchid 2012), } & \text { Phoenix } \\
\text { (Stabler et al. 2005) } & \end{array}$ & 4.43 & 6.8 & 2 \\
\hline \multirow[t]{3}{*}{$\begin{array}{l}\text { C: Temperate } \\
\text { Climate }\end{array}$} & Mediterranean & $\begin{array}{l}\text { Athens (Skoulika et al. 2014; Zoulia } \\
\text { et al. 2009), Lisbon (Andrade and } \\
\text { Alcoforado 2008; Oliveira et al. } \\
\text { 2011), Chania (Georgi and } \\
\text { Dimitriou 2010), Tel Aviv (Potchter } \\
\text { et al. 2006; Shashua-Bar and } \\
\text { Hoffman 2000), Florence (Bacci et } \\
\text { al. 2003), Valencia (Gomez et al. } \\
\text { 1998), Sacramento (Spronken- } \\
\text { Smith and Oke 1998), } \\
\text { Lisbon(Alcoforado 1996) }\end{array}$ & 2.8 & 5.7 & 0.7 \\
\hline & Subtropical & $\begin{array}{l}\text { Delhi(Padmanabha Murty and } \\
\text { Seshu Tangirala 1990), MexicoCity } \\
\text { (Barradas 1991; Jauregui 1991), } \\
\text { Fukuoka (Katayama et al. 1993), } \\
\text { Taipei (Chang et al. 2007), Tokyo } \\
\text { (Thorsson et al. 2007), Nagoya (Cao } \\
\text { et al. 2010; Hamada and Ohta 2010; } \\
\text { Hamada et al. 2013), Chongqing (Lu } \\
\text { et al. 2012), Saga (Srivanit and } \\
\text { Kazunori 2011), Nanjing (Kong et } \\
\text { al. 2014) }\end{array}$ & 2.5 & 6.8 & 0.3 \\
\hline & Oceanic & $\begin{array}{l}\text { Go“teborg (Lindqvist 1992; } \\
\text { Upmanis et al. 1998), Vancouver } \\
\text { (Spronken-Smith and Oke 1998), } \\
\text { London (Doick et al. 2014; Watkins } \\
\text { et al. 2002), Seattle (Kjelgren and } \\
\text { Montague 1998), Essen (Lahme and } \\
\text { Bruse 2003), Portland (Taleghani et } \\
\text { al. 2014) }\end{array}$ & 2.1 & 6 & 0.5 \\
\hline \multicolumn{2}{|c|}{ D: Continental Climate } & $\begin{array}{l}\text { Seoul (Lee et al. 2009), Kumamoto } \\
\text { (Saito et al. 1991), Montreal (Oke et } \\
\text { al. 1989), Stockholm (Jansson et al. } \\
\text { 2007) }\end{array}$ & 1.8 & 4 & 0.5 \\
\hline \multicolumn{2}{|c|}{ E: Polar and alpine Climate } & - & - & - & - \\
\hline
\end{tabular}

\section{The adjacent urban fabric (AUF)}

The cooling effect of greenery in the city not only depends on its specific attributes but also on the surrounding urban fabric, which alters the cooling intensity and cooling extension. Spronken and Oke in their study in Vancouver and Sacramento emphasized that, besides the percentage of trees in a park, irrigation requirements and aridity of the place, the vicinity is an important factor determining the cooling extension (Spronken-Smith and Oke 1998). The importance of the adjacent urban fabric around green spaces has been mentioned in different studies (Jamei et al. 2016; Oke 1987). One of the effects of the surrounding area on GCI is the shadow it casts. Shadow has been reported as a factor that enhances thermal comfort more than purely from its effect on air and surface temperature (Emmanuel et al. 2007). Aspect ratio of urban streets as a factor to quantify urban geometry and calculate shadow 
plays an important role in heat mitigation and thermal comfort (Johansson 2006; Pearlmutter et al. 2006). If the aspect ratio equals to 2 or more, it means that a corridor or street is deep (Ahmad et al. 2005). Although in streets with tall surrounding buildings (deep streets), because of shadow, the temperature is lower than in streets with lower buildings (shallow streets), studies have shown that the cooling effect of trees in shallow streets is higher than in deep streets (Shashua-Bar et al. 2006; Srivanit and Kazunori 2011). Similar results have been reported for Lisbon, where the GCI in East-West streets was significantly higher than in North-South streets (Oliveira et al. 2011). Because of sun exposure, in E-W streets the thermal condition is worse than in N-S streets (Johansson 2006). Adding trees to E-W streets as a passive method to alleviate heat stress has been suggested especially for hot and dry climates (Toudert 2005).The shape of the built environment is another factor which alters shadow and GCI. Shashua-Bar et al. (Limor Shashua-Bar et al. 2006) calculated - that colonnades in urban streets as a factor in built form intensified GCI . They demonstrated that adding $70 \%$ of shadow from trees to a street with and without colonnade could decrease the air temperature by 2.8 and $2.0 \mathrm{~K}$ respectively. Another study showed that adding a mesh over grass, which causes a shadow, is an effective method to increase the GCI (Shashua-Bar et al. 2009).

The Wind is a meteorological parameter which is important for pedestrian comfort. In summer especially in hot-humid climates, its cooling role is imperative. Erell (Erell et al. 2012) (2012) demonstrated that a wind speed of about 1-1.5 m/s dropped the air temperature by about $2 \mathrm{~K}$ in cities. A similar study in Greece illustrated that various wind speeds decreased the air temperature up to $5 \mathrm{~K}$ (Georgakis and Santamouris 2006). Wind speed and direction can change the cooling intensity and cooling extension of vegetated areas. The built environment can alter wind patterns in urban spaces. By blocking the wind flow to the surrounding areas or channeling the wind and increasing its speed, the built environment has an effect on GCI. Oke (Oke et al. 1989) (1989) reported from a study in Montreal that a wind speed of more than $6 \mathrm{~m} / \mathrm{s}$ could have the vegetation cooling effect disappear. Similar results from a recent study in London illustrated that during low wind speed the cooling extension of vegetated areas was greatest (Doick et al. 2014). Taha(Taha et al. 1989) concluded that in an upwind field the difference between the temperature of an orchard and an open space is bigger than in a downwind field. Another study showed that by increasing the height of buildings and blocking the wind flow the cooling extension of greenery will be decreased (Fryd et al. 2011). In addition, in this condition there might already be a lot of shadow from the buildings causing a decrease in the plant's role in heat mitigation (Pearlmutter et al. 2006); see also the previous paragraph. In a study in Gothenburg, Sweden, no noticeable cooling extension was found because the park was directly enclosed by buildings (Upmanis et al. 1998). Similar results were reported by Saito et al. in Kumamoto, Japan (Saito et al. 1991). Eliasson et al. in their study illustrated that topography and slopes as factors in blocking nocturnal airflow from urban parks decreased GCI (Eliasson and Upmanis 2000). The direction of urban corridors is another factor of the built environment which changes wind patterns and velocity(Niachou et al. 2008). If streets are oriented towards the prevailing wind, the wind can penetrate deeper into the city (Santamouris et al. 2008). Several studies showed that an optimal orientation could decrease the temperature in the city ( $\mathrm{Ng}$ et al. 2011; Taleb and Taleb 2014). In summary, many parameters of the urban geometry affect airflow and thereby change GCI. Urban density, the height of buildings and their arrangement are the factors mentioned most (Hamada et al. 2013; Hsieh and Wu 2012; Zoulia et al. 2009). These studies show that with a right orientation of streets and green corridors, wind channels with a moderate speed could be made. A moderate wind speed increases the cooling extension of green corridors and green patches in a city and can be used to decrease heat islands.

Urban land use has a pronounced effect on the GCI. With a study in Arizona, Stabler concluded that commercial and industrial land uses significantly have higher temperatures and lower NDVI compared to residential land uses (Stabler et al. 2005). In a previous study, he analyzed 107 randomly chosen sites and showed for different urban land uses, plant density was different which directly 
affected temperature. (Stabler 2003). Also, Hamada et al. (Hamada et al. 2013) (2013) studied the relation between land-use types, surface temperature, and cooling extension. They showed that by approaching a park the temperature decreased in all land-uses. However, the cooling extension was less in commercial land uses as compared to other land uses. Although land use is a practical factor influencing GCI, there are not sufficient studies taking land use into account in order to draw clear conclusions.

Traffic is another factor that may decrease the cooling extension. Heat released by vehicle traffic may increase the temperature. Zoulia et al. (Zoulia et al. 2009) (2009) showed that the cooling extension of a large park in Athens was negligible because of heavy traffic. Another study showed a maximum reduction in air temperature by about $1.8 \mathrm{~K}$ by increasing tree canopy cover from $7.8 \%$ to $50 \%$, while the maximum reduction in air temperature by decreasing the traffic load from 1500 to 750 vehicles per hour was $0.7 \mathrm{~K}$. These changes in green canopy cover and traffic load also decreased PET by about $8.3^{\circ} \mathrm{C}$ and $1.1{ }^{\circ} \mathrm{C}$ respectively (Shashua-Bar et al. 2012). Heavy traffic in a street decreased the GCI by around $3 \mathrm{~K}$ in Tel-Aviv (Shashua-Bar and Hoffman 2000).

A desirable combination of built-up geometry and green space based on their shadow and wind flow based on climatic type can mitigate temperature. Heat produced in the surroundings of greenery, like heat from traffic, may reduce the cooling extension of greenery. In commercial districts with a high traffic load, the cooling extension is insignificant. Thus an adequate distribution of commercial zones and traffic in a city in combination with sufficient greenery in these zones may increase GCI.

\section{Conclusion}

Increased temperatures in cities are an important consideration today. Many studies have suggested urban greening to mitigate these high temperatures. Vegetated areas, especially areas with trees, could make the micro-climate more comfortable for people not only by shading and inhibiting penetration of solar radiation but also by evaporating water and circulating air. The cooling effects of green spaces can be studied in two parameters, cooling intensity and cooling extension.

Studies into cooling intensity have shown that the cooling effect of urban green spaces varies between 0.2-6.8 K, although the temperature of green areas in some studies was higher than of their surroundings due to less shadow of some species, the heat released by grass decomposition, the midday photosynthesis and paved surfaces inside the green spaces. Studies reported similar effects for surface temperature and air temperature. However, the green space's effect on thermal comfort is more than its effect on air and surface temperature. Adding shading trees decreased PET up to a maximum of $20^{\circ} \mathrm{C}$ which emphasizes the importance of greenery as a passive cooling method. For cooling intensity, the size of the green site, its shape, plant species, (micro-)climate and tree canopy cover are the main important indexes.

The cooling extension was found to vary between $0.2-1.4 \mathrm{~K}$ per $100 \mathrm{~m}$ showing a wide range due to varying factors that affect this distance. A high and dense urban fabric around green spaces may block a breeze; traffic and land use type may also affect cooling distance. In addition, the shape index is an internal factor which affects cooling extension.

The main results based on each index are:

Size index is one of the important issues under discussion concerning the cooling effect. Although even small green spaces can decrease the temperature, most of the studies indicated that the larger the park, the stronger the effect. Parks smaller than 3 ha were not always cooler than their surroundings while larger parks were consistently cooler. In addition, all parks which were warmer than their surroundings were smaller than 2 ha.

Shape index is a factor with a negative correlation with cooling intensity and a positive correlation with cooling extension. Based on the exact location, different shapes will be effective. For instance, in the 
districts of a city in which a heat island is detected and the cooling intensity is more important, e.g. in a city center, a regular shape is suggested. In other districts that require a large cooling distance to mitigate the temperature in a larger area, e.g. in neighborhoods, irregular shapes will be effective.

The canopy cover, covering urban space by shading trees is a method to control solar radiation and make cool islands in the morning. Based on the climate, the specific situation in the city and also the site, the optimum TCC is different. For example in a city with hot summers and mild winters, adding more shading trees will be effective. In contrast, in a city center with a night heat island, covering the urban spaces with trees will intensify the problem.

Species index with physical properties and metabolic behavior also affect temperature. The physical properties of each species which influence the leaf area, the density, and shading quality can mitigate temperature. Besides, some other characteristics, e.g. leaf color lightness, foliage density, leaf thickness, and leaf texture (surface roughness), also play a role in the cooling effect. Time of photosynthesis and amount of moisture transpired are other properties of plants which change the temperature. The exact problem will define which plants to select. For instance, in a city with hot days, shading trees are more effective than grass while in a city with a night heat island, grassland is more effective because its surface temperature drops fast

The climate is an imperative factor which affects the GCI. The higher the temperature and the drier the climate, the higher the cooling effect of greenery in summer. In arid and semi-arid climates, the effects of planted areas were not only limited to surface and air temperature but also included the increase of humidity and the creation of cool breezes.

The adjacent urban fabric influences both the cooling intensity and cooling extension, by changing the amount of shadow in the city and by altering wind patterns. In addition land use has an effect on the GCI, for instance, commercial land uses to decrease the cooling effect. Also, heat produced by traffic is another factor which decreases or even vanishes the cooling extension.

In the time of climate change and global warming, urban designers and planners can apply passive methods to impact thermal comfort. Decision making based on climatic considerations may guide cities to sustainable urban development. The indexes which were extracted from the literature, regarding the climate zone, the specific problem and different targets may mitigate heat stress and make cities better places to live.

\section{Acknowledgement}

The authors appreciate cooperation and consultation of Professor Andy van den Dobbelsteen from the Climate Design \& Sustainability at the Faculty of Architecture of TU Delft.

\section{References}

Ahmad K, Khare M, Chaudhry K (2005) Wind tunnel simulation studies on dispersion at urban street canyons and intersections - a review. Journal of Wind Engineering and Industrial Aerodynamics, 93(9), 697-717.

Ahmad S (1992) Some effects of urban parks on air temperature variations in Kuala Lumpur, Malaysia. Paper presented at the 2nd Tohwa University International Symposium, CUTEST.

Aithal BH, Sanna DD (2012). Insights to urban dynamics through landscape spatial pattern analysis. International Journal of Applied Earth Observation and Geoinformation, 18, 329-343.

Akbari H (2009) Cooling our communities. A guidebook on tree planting and light-colored surfacing. United states Enviromental Protection Agency, P221.

Akbari H, Levinson R (2008) Evolution of cool-roof standards in the US. Advances in building energy research, 2(1), 1-32.

Akbari H, Pomerantz M, Taha H (2001) Cool surfaces and shade trees to reduce energy use and improve air quality in urban areas. Solar energy, 70(3), 295-310. 
Akbari H, Taha H (1992) The impact of trees and white surfaces on residential heating and cooling energy use in four Canadian cities. Energy, 17(2), 141-149.

Alcoforado M (1996) Comparaison des ambiances bioclimatiques estivales d'espaces verts de Lisbonne. Publications de l'Association Internationale de Climatologie, 9, 273-280.

Ali-Toudert F, Mayer H (2007) Effects of asymmetry, galleries, overhanging facades and vegetation on thermal comfort in urban street canyons. Solar energy, 81(6), 742-754.

Andrade H, Alcoforado MJ (2008) Microclimatic variation of thermal comfort in a district of Lisbon (Telheiras) at night. Theoretical and Applied Climatology, 92(3-4), 225-237.

Arnfield AJ (2003) Two decades of urban climate research: a review of turbulence, exchanges of energy and water, and the urban heat island. International journal of climatology, 23(1), 1-26.

Bacci L, Morabito M, Raschi A, Ugolini F (2003) Thermohygrometric conditions of some urban parks of Florence (Italy) and their effects on human well-being. trees, 6, 49.

Baccini M, Kosatsky T, Analitis A, Anderson HR, D'Ovidio M, Menne B, Group PC (2011) Impact of heat on mortality in 15 European cities: attributable deaths under different weather scenarios. Journal of epidemiology and community health, 65(1), 64-70.

Barradas VL (1991) Air temperature and humidity and human comfort index of some city parks of Mexico City. International journal of biometeorology, 35(1), 24-28.

Bernatzky A (1982) The contribution of tress and green spaces to a town climate. Energy and buildings, 5(1), 1-10.

Boukhabl M, Alkam D (2012) Impact of vegetation on thermal conditions outside, Thermal modeling of urban microclimate, Case study: the street of the republic, Biskra. Energy Procedia, 18, 73-84.

Bowler DE, Buyung-Ali L, Knight TM, Pullin AS (2010) Urban greening to cool towns and cities: A systematic review of the empirical evidence. Landscape and Urban Planning, 97(3), 147-155.

Bréda N, Granier A (1996) Intra-and interannual variations of transpiration, leaf area index and radial growth of a sessile oak stand (Quercus petraea). Paper presented at the Annales des sciences forestières.

Burden D (2008) 22 Benefits of Urban Street Trees: Glatting.

Buyadi SNA, Mohd WMNW, Misni A (2013) Green Spaces Growth Impact on the Urban Microclimate. Procedia-Social and Behavioral Sciences, 105, 547-557.

Ca VT, Asaeda T, Abu EM (1998) Reductions in air conditioning energy caused by a nearby park. Energy and buildings, 29(1), 83-92.

Cao X, Onishi A, Chen J, Imura H (2010) Quantifying the cool island intensity of urban parks using ASTER and IKONOS data. Landscape and Urban Planning, 96(4), 224-231.

Chandler TJ (1966) The climate of London. New York JSTOR.

Chang CR, Li MH, Chang SD (2007) A preliminary study on the local cool-island intensity of Taipei city parks. Landscape and Urban Planning, 80(4), 386-395.

Charalampopoulos I, Tsiros I, Chronopoulou-Sereli A, Matzarakis A (2013) Analysis of thermal bioclimate in various urban configurations in Athens, Greece. Urban Ecosystems, 16(2), 217-233.

Chen A, Yao XA, Sun R, Chen L (2014) Effect of urban green patterns on surface urban cool islands and its seasonal variations. Urban forestry \& urban greening, 13(4), 646-654.

Chen X, Su Y, Li D, Huang G, Chen W, Chen S (2012) Study on the cooling effects of urban parks on surrounding environments using Landsat TM data: a case study in Guangzhou, southern China. International journal of remote sensing, 33(18), 5889-5914.

Chen Y, Wong Nyuk H (2006) Thermal benefits of city parks. Energy and buildings, 38(2), 105-120.

Clarke JF (1972) Some effects of the urban structure on heat mortality. Environmental research, 5(1), 93-104.

Correa E, Ruiz MA, Canton A, Lesino G (2012) Thermal comfort in forested urban canyons of low building density. An assessment for the city of Mendoza, Argentina. Building and environment, 58, 219-230.

De Bruin H, Jacobs C (1993) Impact of CO2 enrichment on the regional evapotranspiration of agroecosystems, a theoretical and numerical modelling study. Vegetatio, 104(1), 307-318.

Declet-Barreto J, Brazel AJ, Martin CA, Chow WT., Harlan SL (2013) Creating the park cool island in an inner-city neighborhood: heat mitigation strategy for Phoenix, AZ. Urban Ecosystems, 16(3), 617-635. 
Armaghan Ahmadi Venhari et al.

Doick KJ, Peace A, Hutchings TR (2014) The role of one large greenspace in mitigating London's nocturnal urban heat island. Science of The Total Environment, 493, 662-671.

Ehleringer J (1985) Comparative microdimatology and plant responses in Encelia species from contrasting habitats. Journal of arid environments, 8, 45-56.

Eliasson I, Upmanis H (2000) Nocturnal airflow from urban parks-implications for city ventilation. Theoretical and Applied Climatology, 66(1-2), 95-107.

Elsayed IS (2012) Mitigation of the urban heat island of the city of Kuala Lumpur, Malaysia. MiddleEast Journal of Scientific Research, 11(11), 1602-1613.

Emmanuel R, Rosenlund H, Johansson E (2007) Urban shading - a design option for the tropics? A study in Colombo, Sri Lanka. International journal of climatology, 27(14), 1995-2004.

Erell E, Pearlmutter D, Williamson T (2012) Urban microclimate: designing the spaces between buildings. London: Routledge.

Escourrou G (1981) Climat et environnement: les facteurs locaux du climat. Paris: Masson Paris.

Fan C, Myint S (2014) A comparison of spatial autocorrelation indices and landscape metrics in measuring urban landscape fragmentation. Landscape and Urban Planning, 121, 117-128.

Feyisa GL, Dons K, Meilby H (2014) Efficiency of parks in mitigating urban heat island effect: An example from Addis Ababa. Landscape and Urban Planning, 123, 87-95.

Fiala A, Garman SL, Gray AN (2006) Comparison of five canopy cover estimation techniques in the western Oregon Cascades. Forest Ecology and Management, 232(1), 188-197.

Fryd O, Pauleit S, Bühler O (2011) The role of urban green space and trees in relation to climate change. CAB Reviews: Perspectives in Agriculture, Veterinary Science, Nutrition and Natural Resources, 6(053).

Gehl J (2013) Cities for people: Island press.

Georgakis C, Santamouris M (2006) Experimental investigation of air flow and temperature distribution in deep urban canyons for natural ventilation purposes. Energy and buildings, 38(4), 367-376.

Georgi JN, Dimitriou D (2010) The contribution of urban green spaces to the improvement of environment in cities: Case study of Chania, Greece. Building and environment, 45(6), 1401-1414.

Georgi N, Zafiriadis K (2006) The impact of park trees on microclimate in urban areas. Urban Ecosystems, 9(3), 195-209.

Ghiaus C, Allard F, Santamouris M, Georgakis C, Nicol F (2006) Urban environment influence on natural ventilation potential. Building and environment, 41(4), 395-406.

Gill S, Handley J, Ennos A, Pauleit S (2007) Adapting cities for climate change: the role of the green infrastructure. Built Environment (1978-), 115-133.

Gillies RR, Carlson TN (1995) Thermal remote sensing of surface soil water content with partial vegetation cover for incorporation into climate models. Journal of Applied Meteorology, 34(4), 745756.

Givoni B (1972) Comparing temperature and humidity conditions in an urban garden and in its surrounding areas. Retrieved from

Givoni B (1991) Impact of planted areas on urban environmental quality: a review. Atmospheric Environment. Part B. Urban Atmosphere, 25(3), 289-299.

Gomez F, Gaja E, Reig A (1998) Vegetation and climatic changes in a city. Ecological engineering, 10(4), 355-360.

Goyal R (2004) Sensitivity of evapotranspiration to global warming: a case study of arid zone of Rajasthan (India). Agricultural Water Management, 69(1), 1-11.

Grimmond C, Souch C, Hubble M (1996) Influence of tree cover on summer-time surface energy balance fluxes, San Gabriel Valley, Los Angeles. Climate Research, 6(1), 45-57.

Hamada S, Ohta T (2010) Seasonal variations in the cooling effect of urban green areas on surrounding urban areas. Urban forestry \& urban greening, 9(1), 15-24.

Hamada S, Tanaka T, Ohta T (2013) Impacts of land use and topography on the cooling effect of green areas on surrounding urban areas. Urban forestry \& urban greening, 12(4), 426-434.

Hardin PJ, Jensen RR (2007) The effect of urban leaf area on summertime urban surface kinetic temperatures: a Terre Haute case study. Urban forestry \& urban greening, 6(2), 63-72.

Honjo T, Takakura T (1991) Simulation of thermal effects of urban green areas on their surrounding areas. Energy and buildings, 15(3), 443-446. 
Armaghan Ahmadi Venhari et al.

Höppe P (1999) The physiological equivalent temperature-a universal index for the biometeorological assessment of the thermal environment. International journal of biometeorology, 43(2), 71-75.

Hsieh C, Wu K (2012) Climate-sensitive urban design measures for improving the wind environment for pedestrians in a transit-oriented development area. Journal of Sustainable Development, 5(4), 46.

Huang Y, Akbari H, Taha H (1990) The wind-shielding and shading effects of trees on residential heating and cooling requirements. Retrieved from

Jamei E, Rajagopalan P, Seyedmahmoudian M, Jamei Y (2016) Review on the impact of urban geometry and pedestrian level greening on outdoor thermal comfort. Renewable and Sustainable Energy Reviews, 54, 1002-1017.

Jansson C, Jansson PE, Gustafsson D (2007) Near surface climate in an urban vegetated park and its surroundings. Theoretical and Applied Climatology, 89(3-4), 185-193.

Jauregui E (1991) Influence of a large urban park on temperature and convective precipitation in a tropical city. Energy and buildings, 15(3), 457-463.

Jendritzky G (1990) Methodik zur räumlichen Bewertung der thermischen Komponente im Bioklima des Menschen: fortgeschriebenes Klima-Michel-Modell: na.

Jennings S, Brown N, Sheil D (1999) Assessing forest canopies and understorey illumination: canopy closure, canopy cover and other measures. Forestry, 72(1), 59-74.

Johansson E (2006) Influence of urban geometry on outdoor thermal comfort in a hot dry climate: a study in Fez, Morocco. Building and environment, 41(10), 1326-1338.

Johansson E, Spangenberg J, Gouvêa ML, Freitas ED (2013) Scale-integrated atmospheric simulations to assess thermal comfort in different urban tissues in the warm humid summer of São Paulo, Brazil. Urban Climate, 6, 24-43.

Jonsson P (2004) Vegetation as an urban climate control in the subtropical city of Gaborone, Botswana. International journal of climatology, 24(10), 1307-1322.

Kai K, Matsuda M, Sato R (1997) Oasis effect observed at Zhangye oasis in the Hexi corridor, China. Journal of the Meteorological Society of Japan, 75(6), 1171-1178.

Karlessi T, Santamouris M, Synnefa A, Assimakopoulos D, Didaskalopoulos P, Apostolakis K (2011) Development and testing of PCM doped cool colored coatings to mitigate urban heat island and cool buildings. Building and environment, 46(3), 570-576.

Katayama E, Fukuda T, Nozawa H (1993) Light trap monitoring of the stink bugs attacking fruit trees and their ovarian development. Japan: Bulletin of the Tochigi Prefectural Agricultural Experiment Station

Kawashima S (1991) Effect of vegetation on surface temperature in urban and suburban areas in winter. Energy and buildings, 15(3), 465-469.

Kjelgren R, Montague T (1998) Urban tree transpiration over turf and asphalt surfaces. Atmospheric Environment, 32(1), 35-41.

Klemm W, Heusinkveld BG, Lenzholzer S, Jacobs MH, Van Hove B (2015) Psychological and physical impact of urban green spaces on outdoor thermal comfort during summertime in The Netherlands. Building and environment, 83, 120-128.

Kong F, Yin H, James P, Hutyra LR, He HS (2014) Effects of spatial pattern of greenspace on urban cooling in a large metropolitan area of eastern China. Landscape and Urban Planning, 128, 35-47.

Kotzen B (2003) An investigation of shade under six different tree species of the Negev desert towards their potential use for enhancing micro-climatic conditions in landscape architectural development. Journal of arid environments, 55(2), 231-274.

Kumar R, Kaushik S (2005) Performance evaluation of green roof and shading for thermal protection of buildings. Building and environment, 40(11), 1505-1511.

Lahme E, Bruse M (2003) Microclimatic effects of a small urban park in densely built-up areas: measurements and model simulations. ICUC5, Lodz, 5(1).

Lee SH, Lee KS, Jin WC, Song HK (2009) Effect of an urban park on air temperature differences in a central business district area. Landscape and Ecological Engineering, 5(2), 183-191.

Leuzinger S, Vogt R, Körner C (2010) Tree surface temperature in an urban environment. Agricultural and Forest Meteorology, 150(1), 56-62.

Liérbard A, De Herde A (2005) Traité d'architecture et d'urbanisme bioclimatiques. Concevoir, édifier et aménager avec le développement durable», Edition Le moniteur. 
Environment, Earth and Ecology Vol. 1 No. 1 (2017), 5-32

Armaghan Ahmadi Venhari et al.

Lin BS, Lin YJ (2010) Cooling effect of shade trees with different characteristics in a subtropical urban park. HortScience, 45(1), 83-86.

Lin TP, Matzarakis A, Hwang RL (2010) Shading effect on long-term outdoor thermal comfort. Building and environment, 45(1), 213-221.

Lin W, Yu T, Chang X, Wu W, Zhang Y (2015) Calculating cooling extents of green parks using remote sensing: Method and test. Landscape and Urban Planning, 134, 66-75.

Lindqvist S (1992) Local climatological modelling for road stretches and urban areas. Geografiska Annaler. Series A. Physical Geography, 265-274.

Liu Y, Shintaro G, Zhuang D, Kuang W (2012) Urban surface heat fluxes infrared remote sensing inversion and their relationship with land use types. Journal of Geographical Sciences, 22(4), 699715.

Lu J, Li Cd, Yang Yc, Zhang Xh, Jin M (2012) Quantitative evaluation of urban park cool island factors in mountain city. Journal of Central South University, 19, 1657-1662.

McGarigal K (2002) Landscape pattern metrics. Encyclopedia of environmetrics.

McPherson EG, Simpson JR (2003) Potential energy savings in buildings by an urban tree planting programme in California. Urban forestry \& urban greening, 2(2), 73-86.

Medina-Ramón M, Schwartz J (2007) Temperature, temperature extremes, and mortality: a study of acclimatisation and effect modification in 50 US cities. Occupational and environmental medicine, 64(12), 827-833.

McPherson E (1998) Air pollution uptake by sacramento's urban forest. Journal of Arboriculture, 24(4), 6-9.

Monteiro LM, Alucci MP (2009) An Outdoor Thermal Comfort Index for the Subtropics. Proceeding 26th PLEA.

Mullaney J, Lucke T, Trueman SJ (2015) A review of benefits and challenges in growing street trees in paved urban environments. Landscape and Urban Planning, 134, 157-166.

$\mathrm{Ng}$ E, Chen L, Wang Y, Yuan C (2012) A study on the cooling effects of greening in a high-density city: an experience from Hong Kong. Building and environment, 47, 256-271.

$\mathrm{Ng}$ E, Yuan C, Chen L, Ren C, Fung JC (2011) Improving the wind environment in high-density cities by understanding urban morphology and surface roughness: a study in Hong Kong. Landscape and Urban Planning, 101(1), 59-74.

Niachou A, Papakonstantinou K, Santamouris M, Tsangrassoulis A, Mihalakakou G (2001) Analysis of the green roof thermal properties and investigation of its energy performance. Energy and buildings, 33(7), 719-729.

Niachou K, Livada I, Santamouris M (2008) Experimental study of temperature and airflow distribution inside an urban street canyon during hot summer weather conditions. Part II: airflow analysis. Building and environment, 43(8), 1393-1403.

Nichol JE (1996) High-resolution surface temperature patterns related to urban morphology in a tropical city: a satellite-based study. Journal of Applied Meteorology, 35(1), 135-146.

Nowak DJ, Crane DE, Stevens JC (2006) Air pollution removal by urban trees and shrubs in the United States. Urban forestry \& urban greening, 4(3), 115-123.

O'Neill MS, Ebi KL (2009) Temperature extremes and health: impacts of climate variability and change in the United States. Journal of Occupational and Environmental Medicine, 51(1), 13-25.

Oke TR (1982) The energetic basis of the urban heat island. Quarterly Journal of the Royal Meteorological Society, 108(455), 1-24.

Oke TR (1987) Boundary layer climates. Kentucky, US: Psychology Press.

Oke TR, Crowther J, McNaughton K, Monteith J, Gardiner B (1989) The micrometeorology of the urban forest [and discussion]. Philosophical Transactions of the Royal Society of London. B, Biological Sciences, 324(1223), 335-349.

Oliveira S, Andrade H, Vaz T (2011) The cooling effect of green spaces as a contribution to the mitigation of urban heat: A case study in Lisbon. Building and environment, 46(11), 2186-2194.

Padmanabha Murty B, Seshu Tangirala R (1990) An assessment of the assimilative capacity of the atmosphere at Delhi. Atmospheric Environment. Part A. General Topics, 24(4), 845-848.

Patton DR (1975) A diversity index for quantifying habitat" edge". Wildlife Society Bulletin, 171-173.

Pearlmutter D, Berliner P, Shaviv E (2006) Physical modeling of pedestrian energy exchange within the urban canopy. Building and environment, 41(6), 783-795. 
Armaghan Ahmadi Venhari et al.

Peel MC, Finlayson BL, McMahon TA (2007) Updated world map of the Köppen-Geiger climate classification. Hydrology and Earth System Sciences Discussions Discussions, 4(2), 439-473.

Petralli M, Massetti L, Orlandini S (2009) Air temperature distribution in an urban park: Differences between open-field and below a canopy. Paper presented at the The seventh International Conference on Urban Climate, Yokohama, Japan.

Potchter O, Cohen P, Bitan A (2006) Climatic behavior of various urban parks during hot and humid summer in the Mediterranean city of Tel Aviv, Israel. International journal of climatology, 26(12), 1695-1711.

Pugnaire F, Valladares F (1999) Handbook of functional plant ecology. New York: CRC Press.

Ramachandra T, Aithal BH, Sanna DD (2012) Insights to urban dynamics through landscape spatial pattern analysis. International Journal of Applied Earth Observation and Geoinformation, 18, 329343.

Rchid A (2012) The Effects of Green Spaces (Palme Trees) on the Microclimate in Arid Zones, Case Study: Ghardaia, Algeria. Architecture Research, 2(5), 60-67.

Rey JM (1999) Modelling potential evapotranspiration of potential vegetation. Ecological Modelling, 123(2), 141-159.

Rhodes JR, Ng CF, de Villiers DL, Preece HJ, McAlpine CA, Possingham HP (2011) Using integrated population modelling to quantify the implications of multiple threatening processes for a rapidly declining population. Biological Conservation, 144(3), 1081-1088.

Rosenfeld AH, Akbari H, Bretz S, Fishman BL, Kurn DM, Sailor D, Taha H (1995) Mitigation of urban heat islands: materials, utility programs, updates. Energy and buildings, 22(3), 255-265.

Rosenfeld AH, Akbari H, Romm JJ, Pomerantz M (1998) Cool communities: strategies for heat island mitigation and smog reduction. Energy and buildings, 28(1), 51-62.

Saito I, Ishihara O, Katayama T (1991) Study of the effect of green areas on the thermal environment in an urban area. Energy and buildings, 15(3), 493-498.

Sani S (1987) Urbanization and the atmospheric environment in the low tropics: experiences from the Kelang valley region Malaysia. MIMOS, 2(2).

Santamouris M (2007) Advances in passive cooling (buildings, energy and solar technology series). Earthscan, Sterling.

Santamouris M, Georgakis C, Niachou A (2008) On the estimation of wind speed in urban canyons for ventilation purposes-Part 2: Using of data driven techniques to calculate the more probable wind speed in urban canyons for low ambient wind speeds. Building and environment, 43(8), 1411-1418.

Santamouris M, Papanikolaou N, Livada I, Koronakis I, Georgakis C, Argiriou A, Assimakopoulos D (2001) On the impact of urban climate on the energy consumption of buildings. Solar energy, 70(3), 201-216.

Santamouris M, Xirafi F, Gaitani N, Spanou A, Saliari M, Vassilakopoulou, K (2012) Improving the Microclimate in a Dense Urban Area Using Experimental and Theoretical Techniques-The Case of Marousi, Athens. International Journal of Ventilation, 11(1), 1-16.

Schwarz N, Schlink U, Franck U, Großmann K (2012) Relationship of land surface and air temperatures and its implications for quantifying urban heat island indicators - an application for the city of Leipzig (Germany). Ecological Indicators, 18, 693-704.

Shashua-Bar L, Hoffman M (2000) Vegetation as a climatic component in the design of an urban street: An empirical model for predicting the cooling effect of urban green areas with trees. Energy and buildings, 31(3), 221-235.

Shashua-Bar L, Hoffman ME, Tzamir Y (2006) Integrated thermal effects of generic built forms and vegetation on the UCL microclimate. Building and environment, 41(3), 343-354.

Shashua-Bar L, Pearlmutter D, Erell E (2009) The cooling efficiency of urban landscape strategies in a hot dry climate. Landscape and Urban Planning, 92(3), 179-186.

Shashua-Bar L, Tsiros IX, Hoffman M (2012) Passive cooling design options to ameliorate thermal comfort in urban streets of a Mediterranean climate (Athens) under hot summer conditions. Building and environment, 57, 110-119.

Shen T, Chow D, Darkwa J (2013) Simulating the influence of microclimatic design on mitigating the Urban Heat Island effect in the Hangzhou Metropolitan Area of China. International Journal of LowCarbon Technologies, 1(1). 
Environment, Earth and Ecology Vol. 1 No. 1 (2017), 5-32

Armaghan Ahmadi Venhari et al.

Simpson JR, McPherson EG (1998) Simulation of tree shade impacts on residential energy use for space conditioning in Sacramento. Atmospheric Environment, 32(1), 69-74.

Skoulika F, Santamouris M, Kolokotsa D, Boemi N (2014) On the thermal characteristics and the mitigation potential of a medium size urban park in Athens, Greece. Landscape and Urban Planning, 123, 73-86.

Sonne JK, Vieira R (2000) Cool neighborhoods: the measurement of small scale heat islands. Paper presented at the Proceedings of.

Spangenberg J, Shinzato P, Johansson E, Duarte D (2008) Simulation of the influence of vegetation on microclimate and thermal comfort in the city of São Paulo. Revista da Sociedade Brasileira de Arborização Urbana, 3, 1-19.

Spronken-Smith R, Oke T (1998) The thermal regime of urban parks in two cities with different summer climates. International journal of remote sensing, 19(11), 2085-2104.

Spronken-Smith RA (1994) Energetics and cooling in urban parks. (Ph.D thesis), University of British Columbia, British Columbia, Canada.

Srivanit M, Hokao K (2013) Evaluating the cooling effects of greening for improving the outdoor thermal environment at an institutional campus in the summer. Building and environment, 66, 158172.

Srivanit M, Kazunori H (2011) The Influence of Urban Morphology Indicators on Summer Diurnal Range of Urban Climate in Bangkok Metropolitan Area, Thailand. International Journal of Civil \& Environmental Engineering, 11(5), 34-46.

Stabler LB (2003) Ecosystem function of urban plants in response to landscape management.

Stabler LB, Martin CA, Brazel AJ (2005) Microclimates in a desert city were related to land use and vegetation index. Urban forestry \& urban greening, 3(3), 137-147.

Svensson MK (2004) Sky view factor analysis-implications for urban air temperature differences. Meteorological applications, 11(03), 201-211.

Synnefa A, Santamouris M, Apostolakis K (2007) On the development, optical properties and thermal performance of cool colored coatings for the urban environment. Solar energy, 81(4), 488-497.

Taha H, Akbari H, Rosenfeld A (1991) Heat island and oasis effects of vegetative canopies: micrometeorological field-measurements. Theoretical and Applied Climatology, 44(2), 123-138.

Taha HG, Akbari H, Rosenfeld AH (1989) Vegetation Canopy Micro-climate: A Field-project in Davis, California: Applied Science Division, Lawrence Berkeley Laboratory, University of CaliforniaBerkeley.

Takakura T, Kitade S, Goto E (2000) Cooling effect of greenery cover over a building. Energy and buildings, 31(1), 1-6.

Taleb H, Taleb D (2014) Enhancing the thermal comfort on urban level in a desert area: Case study of Dubai, United Arab Emirates. Urban forestry \& urban greening, 13(2), 253-260.

Taleghani M, Tenpierik M, van den Dobbelsteen A, Sailor D (2014) Heat mitigation strategies in winter and summer: field measurements in temperate climates. Building and environment, 81, 309-319.

Thorn EC (1959) The discomfort index. Weatherwise, 12, 59-60.

Thorsson S, Honjo T, Lindberg F, Eliasson I, Lim EM (2007) Thermal comfort and outdoor activity in Japanese urban public places. Environment and Behavior.

Toudert FA (2005) Dependence of Outdoor Thermal Comfort on Street Design in Hot and Dry Climate. ( $\mathrm{PhD}$ thesis), Universität Freiburg

Tremeac B, Bousquet P, de Munck C, Pigeon G, Masson V, Marchadier C, . . ., Meunier F (2012) Influence of air conditioning management on heat island in Paris air street temperatures. Applied Energy, 95, 102-110.

Tsiros IX (2010) Assessment and energy implications of street air temperature cooling by shade tress in Athens (Greece) under extremely hot weather conditions. Renewable Energy, 35(8), 1866-1869.

Tuzet A, Perrier A, Leuning R (2003) A coupled model of stomatal conductance, photosynthesis and transpiration. Plant, Cell \& Environment, 26(7), 1097-1116.

UN (2014) World's population increasingly urban with more than half living in urban areas. http://www.un.org/en/development/desa/news/population/world-urbanization-prospects-2014.html.

Upmanis H, Eliasson I, Lindqvist S (1998) The influence of green areas on nocturnal temperatures in a high latitude city (Göteborg, Sweden). International journal of climatology, 18(6), 681-700. 
Vailshery LS, Jaganmohan M, Nagendra H (2013) Effect of street trees on microclimate and air pollution in a tropical city. Urban forestry \& urban greening, 12(3), 408-415.

Vanos JK, Warland JS, Gillespie TJ, Slater GA, Brown RD, Kenny NA (2012) Human energy budget modeling in urban parks in Toronto and applications to emergency heat stress preparedness. Journal of Applied Meteorology and Climatology, 51(9), 1639-1653.

Voogt JA, Oke TR (2003) Thermal remote sensing of urban climates. Remote Sensing of Environment, 86(3), 370-384. doi:http://dx.doi.org/10.1016/S0034-4257(03)00079-8

Wardoyo J, Suprapti A, Wediningsih H (2012) Vegetation configuration as microclimate control strategy in hot humid tropic urban park. Journal of Applied Sciences Research(November), 53065310.

Watkins R, Kolokotroni M, Palmer J, Littlefair P (2002) The London Heat Island- surface and air temperature measurements in a park and street gorges. ASHRAE Transactions, 108(1), 419-427.

Weng Q, Lu D, Schubring J (2004) Estimation of land surface temperature-vegetation abundance relationship for urban heat island studies. Remote Sensing of Environment, 89(4), 467-483.

Wenting W, Yi R, Hengyu Z (2012) Investigation on Temperature dropping effect of Urban Green Space in summer in Hangzhou. Energy Procedia, 14, 217-222.

Wilmers F (1991) Effects of vegetation on urban climate and buildings. Energy and buildings, 15(3), 507-514.

Yamashita S, Sekine K, Shoda M, Yamashita K, Hara Y (1986) On relationships between heat island and sky view factor in the cities of Tama River basin, Japan. Atmospheric Environment (1967), 20(4), 681-686.

Yan H, Wang X, Hao P, Dong L (2012) Study on the microclimatic characteristics and human comfort of park plant communities in summer. Procedia Environmental Sciences, 13, 755-765.

Yan W (2006) Extraction of thermal features using satellite sensed images and discussion of brightness temperature characteristics. Journal of Geography (ChigakuZasshi), 115 (4), 448-465( In Japanese, with English summary).

Yang F, Lau SS, Qian F (2011) Thermal comfort effects of urban design strategies in high-rise urban environments in a sub-tropical climate. Architectural Science Review, 54(4), 285-304.

Yang F, Qian F, Lau SS (2013) Urban form and density as indicators for summertime outdoor ventilation potential: A case study on high-rise housing in Shanghai. Building and environment, 70, 122-137.

Yu C, Hien WN (2006) Thermal benefits of city parks. Energy and buildings, 38(2), 105-120.

Zhan W, Chen Y, Voogt J, Zhou J, Wang J, Liu W, Ma W (2012) Interpolating diurnal surface temperatures of an urban facet using sporadic thermal observations. Building and environment, 57, 239-252.

Zhang B, Xie Gd, Gao Jx, Yang Y (2014) The cooling effect of urban green spaces as a contribution to energy-saving and emission-reduction: A case study in Beijing, China. Building and environment, 76, 37-43.

Zhang Z, Lv Y, Pan H (2013) Cooling and humidifying effect of plant communities in subtropical urban parks. Urban forestry \& urban greening, 12(3), 323-329.

Zhao M, Srebric J (2012) Assessment of green roof performance for sustainable buildings under winter weather conditions. Journal of Central South University, 19(3), 639-644.

Zhu B, Wu K (2001) Preparation and solar reflectance spectra of chameleon-type building coatings. Solar energy, 70(5), 417-422.

Zoulia I, Santamouris M, Dimoudi A (2009) Monitoring the effect of urban green areas on the heat island in Athens. Environmental monitoring and assessment, 156(1-4), 275-292. 